Atmospheric Environment

Elsevier Editorial system(tm) for

Manuscript Draft

Manuscript Number: ATMENV-D-18-00410R2

Title: Aerosol Optical Depth Variability over the Arabian Peninsula as inferred from Satellite Measurements

Article Type: Research Paper

Keywords: Aerosol Optical Depth, Arabian Peninsula, ENSo, Tokar Jet

Corresponding Author: Professor Ibrahim Hoteit, PhD

Corresponding Author's Institution: KAUST

First Author: Ravi Kumar Kunchala, Ph.D.

Order of Authors: Ravi Kumar Kunchala, Ph.D.; Raju Attada, Ph.D.; Hari Prasad Dasari, Ph.D.; Ramesh K Vellore, Ph.D.; Sabique Langodan, Ph.D.; Yasser O Abualnaja, Ph.D.; Ibrahim Hoteit, PhD

Abstract: Aerosol abundance from widespread deserts over the Arabian Peninsula (AP) plays an important role in the regional climate and air quality. This study investigates the spatio-temporal variability of Aerosol optical Depth (AOD) ranging from seasonal to inter-annual time scales during the period 2003-2016 using satellite retrievals from MISR and MODIS, together with ground-based observations from the Aerosol Robotic Network (AERONET) available during the period 2003-2012 over the AP. The MODIS AOD (MISR AOD) observations exhibit 0.81 and 0.85 (0.71 and $0.76)$ correlations with ground-based observations during the wet and dry seasons, respectively. The correlations were also found to be significant with respect to the surface monitoring station at Solar village in Saudi Arabia. Our observational analysis reveals higher (lower) concentrations of AOD during dry (wet) seasons over the AP. The observed AODs indicate similar spatial distributions over annual and seasonal time scales, with high AODs over the Southern Red sea (SR), and the Northeast AP, and lower AODs over the central and southern end of the AP. It is also observed that the AOD exhibits year-to-year variations over different sub-regions of the AP. Analyses of the inter-annual variability over the AP reveals a significant relationship between the AOD and El Niño-Southern Oscillation (ENSO) during the summertime. Furthermore, positive AOD anomalies over the AP can be closely linked with the intensification of the westerly jet at the Tokar Gap during La Niña phases. Enhanced monsoon associated heat low over the AP during La Niña phases further favors greater uplift and saltation of dust from desert regions. 
Ibrahim Hoteit

King Abdullah University of Science and Technology

4700 KAUST

Thuwal 23955-6900

Jeddah, Saudi Arabia

Date: 06 June, 2018

Editor,

Atmospheric Environment

Dear Editor,

Please find the revised version of our manuscript entitled (ATMENV-D-18-00410) "Aerosol Optical Depth Variability over the Arabian Peninsula as inferred from satellite measurements" by K. Ravi Kumar, Raju Attada, Hari Prasad Dasari, Ramesh K. Vellore, Sabique Langodan, Yasser O. Abualnaja, Ibrahim Hoteit to Atmospheric Environment. The paper has been carefully revised as per the reviewers' suggestions. The reviewers' comments and suggestions greatly improved the quality of the manuscript, which we greatly acknowledge. We also enclosed our detailed replies to all the individual points raised by the reviewers. The paragraphs that have undergone major revisions are highlighted in yellow in the manuscript. We hope this revised version will address all the reviewers' concerns and journal requirements. We very much appreciate all the reviewers' efforts and time. We are also grateful for all your editorial efforts.

I am the corresponding author, and my contact information can be found above (in the header).

Please do not hesitate to contact me, If you need anything else.

We look forward to hearing from you.

Sincerely yours,

Ibrahim Hoteit

Email: ibrahim.hoteit@kaust.edu.sa 


\section{Replies to Reviewer \#1}

We appreciate the reviewer's time and efforts in reviewing our manuscript. We also thank him/her for the constructive comments and useful suggestions that helped us improving the quality of our work. We have done our best to address all the reviewer's concerns. Detailed point-by-point replies to the reviewer's comments are highlighted in blue below.

\section{Minor Comments:}

Comment 1: Line 6: Period of study has to be clear for AERONET over AP

These are now included in the revised manuscript. Thank you for the suggestion.

Comment 2: Line 26-28: sentence needs rewriting

Done. The revised text now reads as "These aerosol particles can influence the radiative energy budget of the climate system through direct and indirect effects (e.g., Papadimas et al., 2008; Pawar et al., 2015; Kolhe et al., 2016)".

Comment 3: Line 55: AbdiVishkaee et al., 2012 reference is appeared in the text but not cited in the reference list

Done. Thank you.

Comment 4: Line 63-64 Page 4: rewrite the sentence

Done. It reads now as "Higher AOD concentrations over the desert regions generally correspond to greater atmospheric dust aerosols ".

Comment 6: Page 7 Line 133: reference deMeij should be De Meij

Done.

Comment 7: Page 8 Line 153-154: check the sentence and rewrite

The text was revised. It now reads as "High magnitudes of AODs are observed over the central and eastern AP, the SR, and northern Arabian Sea, while weaker magnitudes are noticeable over Sudan and the north-western part of the AP".

Comment 8: Page 8 - 9 Line 159-161: Sentence is not clear

The sentence was revised and it reads now "The AOD magnitudes generally start to increase from May and peaks in July with a mean value $0.57(0.56)$ and a standard deviation of about 0.08 (0.06) for MODIS (MISR)".

Comment 9: I suggest the authors cross check all the references to ensure conformity with the journal and some of the references are missing and/or uncited references.

We thank the reviewer for the suggestion. All the references were cross checked and all necessary changes were appended in the revised manuscript. 
Comment 10: The manuscript is generally well structured and the Language used is good, apart from a few grammatical that I suggest the authors to proof read before submitting the revision.

We have carefully edited the entire manuscript, which has been proofread by a professional English editing service. Thank you. 


\section{Replies to Reviewer \#2}

We appreciate the reviewer's time and efforts in reviewing our manuscript. We also thank him/her for the constructive comments and useful suggestions that helped us in improving the quality of the manuscript. We have done our best to address all the reviewer's concerns. Detailed point-by-point replies to the reviewer's comments are highlighted in blue below.

Comment 1: Since the monthly AOD products from MODIS, MISR, and AERONET were compared, the methods of monthly AOD calculation need to be briefly introduced and the comparability of the three products needs to be clarified.

We have followed the reviewer's suggestion and added the necessary information in the revised manuscript. It reads now as "Monthly means of AOD computed using hourly observations from the ground-based AERONET database are compared with the monthly MODIS and MISR data products".

Comment 2: The relation between ENSO and aerosol loading is not strong and some other factors, such as the land condition, are not mentioned. A brief description of the factors related to the aerosol loading is needed.

Following the reviewer's comment, we have included a discussion on the important factors that influence the aerosol loading over the AP.

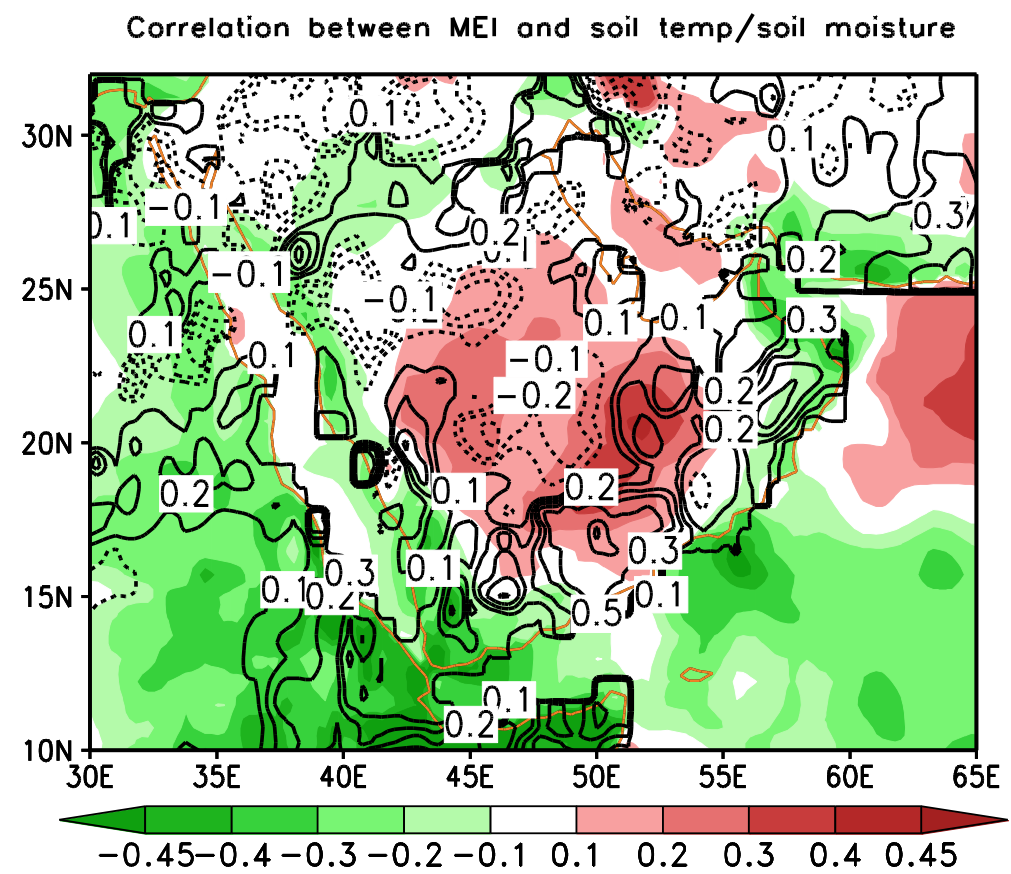

Figure 1: Distribution of soil temperature (contours) and their correlation with MEI (shaded) during summer for the period 2003-2016.

During the summer of the La Niña phases, the geopotential heights over the Arabian Peninsula are low, which favours the required horizontal gradient for dust transportation from the surrounding regions. These conditions also favour the intensification of north-westerly and north-easterly winds, which else generate dust transport over the AP. Therefore, dry conditions during summer of the La Niña phase are conducive to subsequent increased soil 
dryness (less soil moisture and higher soil temperature), which thereby enhance the dust activity over the region. The opposite conditions prevail during the El Niño phase.

Comment 3: The conclusion is not very clear and it looks like a copy of section 3.3 and 3.4. Authors need to rewrite the conclusion and make your arguments clearer.

As suggested, we clarified the conclusions in the revised manuscript.

Comment 4:some wording problems are marked in the attachment.

We thank the reviewer for the suggestions. We have carefully edited the entire manuscript with the help of a professional English editing service. 


\section{Highlights}

AOD variability over the AP is investigated using remote sensing observations

$>$ MODIS and MISR AOD is well correlated with AERONET AOD over the AP

$>$ Inter-annual variability of AOD has a strong relationship with ENSO during summer

$>$ Predominant AOD during La Niña closely linked with the intensification of Tokar jet 
Aerosol Optical Depth Variability over the Arabian Peninsula as inferred from Satellite Measurements K. Ravi Kumar ${ }^{1,2}$, Raju Attada ${ }^{1}$, Hari Prasad Dasari ${ }^{1}$, Ramesh K. Vellore $^{3}$,
Sabique Langdon ${ }^{1}$, Yasser O. Abualnaja ${ }^{1}$, Ibrahim Hoteit ${ }^{*}$ *

${ }^{1}$ Physical Sciences and Engineering division, King Abdullah University of Science and Technology, Thuwal, Saudi Arabia

${ }^{2}$ Centre for Atmospheric Sciences, Indian Institute of Technology (IITD), New Delhi, India

${ }^{3}$ Centre for Climate Change Research, Indian Institute of Tropical Meteorology, Pune, India

*Corresponding author: Prof. Ibrahim Hoteit,

King Abdullah University of Science and Technology (KAUST),

Physical Science and Engineering Division,

Thuwal 23955-6900, Saudi Arabia.

E-mail: ibrahim.hoteit@kaust.edu.sa 


\section{Abstract}

2 Aerosol abundance from widespread deserts over the Arabian Peninsula (AP) plays an important

3 role in the regional climate and air quality. This study investigates the spatio-temporal variability

4 of Aerosol Optical Depth (AOD) ranging from seasonal to inter-annual time scales during the

5 period 2003-2016 using satellite retrievals from MISR and MODIS, together with ground-based

6 observations from the Aerosol Robotic Network (AERONET) available during the period 2003-

72012 over the AP. The MODIS AOD (MISR AOD) observations exhibit 0.81 and 0.85 (0.71 and

8 0.76) correlations with ground-based observations during the wet and dry seasons, respectively.

9 The correlations were also found to be significant with respect to the surface monitoring station

10 at Solar village in Saudi Arabia. Our observational analysis reveals higher (lower) concentrations

11 of AOD during dry (wet) seasons over the AP. The observed AODs indicate similar spatial

12 distributions over annual and seasonal time scales, with high AODs over the Southern Red sea

13 (SR), and the Northeast AP, and lower AODs over the central and southern end of the AP. It is

14 also observed that the AOD exhibits year-to-year variations over different sub-regions of the AP.

15 Analyses of the inter-annual variability over the AP reveals a significant relationship between the

16 AOD and El Niño-Southern Oscillation (ENSO) during the summertime. Furthermore, positive

17 AOD anomalies over the AP can be closely linked with the intensification of the westerly jet at

18 the Tokar Gap during La Niña phases. Enhanced monsoon associated heat low over the AP 19 during La Niña phases further favors greater uplift and saltation of dust from desert regions.

20 Key words: Aerosol Optical Depth, Arabian Peninsula, ENSO, Tokar Jet 


\section{Introduction}

Atmospheric aerosols play a major role in the Earth's radiation budget, hydroclimate, air quality and human health (e.g., Charlson et al., 1992; Ramanathan et al., 2001; Lohmann and 26 Feichter, 2005; Kosmopoulos et al., 2008). Aerosol particles can influence the radiative energy

27 budget of the climate system through direct and indirect effects (e.g., Papadimas et al., 2008;

28 Pawar et al., 2015; Kolhe et al., 2016). Despite the aforementioned significance of aerosols, unraveling their feedback mechanisms is a challenging task because of their multitude of nonspherical shapes and sizes, ranging from desert dust to urban pollutants (Kaufman et al., 2002).

31 Therefore, a comprehensive knowledge of the spatial and temporal distribution of aerosols at 32 global and regional scales is critical to our understanding of their influence on global and local 33 climates. Recently, the Intergovernmental Panel on Climate Change assessment (IPCC, 2013) 34 highlighted the crucial role of the desert dust in influencing the climate variability.

The Arabian Desert is one of the largest source of natural dust in the world, accounting for more than half of the annual mean global dust emissions (e.g., Engelstaedter et al., 2006;

37 Tanaka and Chiba, 2006; Ginoux et al., 2012). The ubiquitous presence of dust storms over the 38 Arabian Peninsula (AP) has significant influence on human life, and these are either locally generated or remotely transported, or a combination of both (Tindale and Pease 1999; Alharbi, 40 2009; Sultan et al. 2013). Regional dust storms are generally triggered by large-scale 41 atmospheric instability and high surface winds over the AP, occurring more frequently over the 42 eastern and southern parts of the AP during the spring and summer seasons (Mashat et al., 2008; 43 Alharbi et al., 2013). Previous studies reported that the variability of aerosol concentrations over 44 the AP is closely associated with the frequency and intensity of dust storms. In particular, an 45 increase in the atmospheric aerosol concentration is expected with an increase in the number or 
46 intensity of dust storm events (Sultan et al., 2013; Nafiseh et al., 2014; Farahat et al., 2015; Xian

47 et al., 2016). Our knowledge about the variability of AP dust storms remains, however

48 essentially constrained due to the limited amount of in situ observations, despite the numerous

49 studies that have effectively exploited available observational datasets (e.g., Mashat et al., 2008;

50 Alharbi, 2009; Alharbi et al., 2013; Maghrabi et al., 2011,2017). Despite the uncertainties in

51 satellite retrievals compared to ground-based observations, several studies have emphasized the

52 importance of satellite remote sensing techniques for analyzing the temporal distribution of dust

53 aerosols at regional and global scales (Liu et al., 2008; Israelevich et al., 2012; Kaskaoutis et al.,

54 2012; AbdiVishkaee et al., 2012). Moreover, satellite retrievals have considerably enhanced our

55 understanding of dust storms including their generation mechanisms, detection and monitoring at

56 regional scales (e.g., Tanre et al., 1997; Schmetz et al., 2002; Schepanski et al., 2012;

57 Sannazzaro et al., 2014).

Aerosol Optical Depth (AOD), is an optical measurement that describes the column-

59 integrated aerosol abundance in the atmosphere, which is commonly obtained from satellites and

60 ground-based instrumentations (Goudie and Middleton, 2006). The Multiangle Imaging

61 SpetroRadiometer (MISR) (Diner et al., 1998) and MOderate Resolution Imaging

62 Spetroradiometer (MODIS) (Kaufman et al., 1997) are two widely used satellite-based

63 instruments for measuring the AOD over land and ocean. The Aerosol Robotic Network

64 (AERONET) provides the ground-truth support (Holben et al., 1998). Higher AOD

65 concentrations over the desert regions generally correspond to greater atmospheric dust aerosols

66 (Yu et al., 2013). A recent study by Maghrabi et al (2017) investigated the variability of the

67 AOD and their trends over the Solar Village observation location $\left(46.41^{\circ} \mathrm{E}, 24.91^{\circ} \mathrm{N}, 764 \mathrm{~m}\right.$ asl),

68 Saudi Arabia. Their results revealed high AOD values during the spring season, which was 
attributed to the effect of dust transport by northeasterly winds from arid and semi-arid regions.

70 All earlier studies in the AP region focused primarily on AOD properties, but no attempts have

71 been made to investigate the variability of AP AOD at various time scales and to infer the role of

72 tropical climate drivers, such as El Niño-Southern Oscillation (ENSO), on the distribution of the

73 AOD over the AP. The aim of this study is to provide new insights into the understanding of the

74 AP aerosol variability ranging from seasonal to inter-annual time scales. We first validate the

75 quality of the AOD values acquired from satellites, using available ground-based observations of

76 AERONET at the Solar village $\left(46.41^{\circ} \mathrm{E}, 24.91^{\circ} \mathrm{N}, 764 \mathrm{~m}\right.$ asl). We then examine the spatial

77 distribution of the AOD at seasonal (dry and wet seasons), inter-annual scales, and their

78 variability over the AP. We further investigate the influence of the prominent large-scale climate

79 driver ENSO on AOD distributions over the AP. This paper is organized as follows: section 2

80 describes the data and methodology, section 3 focuses on the analysis of the results, followed by

81 the summary and conclusions in section 4.

82

\section{Study region, Datasets and Methodology}

The study area is confined to arid regions of the AP mainly covered by large deserts, such as the Ad-Dahna in the eastern AP, An-Nafud in the northern part of the AP, and Rub'Al Khali in the southern AP, which are the main sources of aerosols over this region. The domain includes parts of Saudi Arabia, Oman, United Arab Emirates (UAE), and Yemen, located between the latitudes $12^{\circ} \mathrm{N}-32^{\circ} \mathrm{N}$ and longitudes $30^{\circ} \mathrm{E}-60^{\circ} \mathrm{E}$. The climate of the AP is extremely hot and dry, which favors profound sand and dust activities (Shalaby et al., 2015).

The datasets used in this study are: (i) 36-channeled MISR (Diner et al. 1998; Martonchik et al., 2004; Marey et al., 2011) level 3 products at $558 \mathrm{~nm}$ archived at a horizontal resolution of $0.5^{\circ} \times 0.5^{\circ}$ from the National Aeronautics and Space Administration (NASA), and (ii) combined 
92 dark target and dark blue products from the MODIS Aqua (Ichoku et al., 2002; Levy et al., 2007;

93 2010) Level 3 monthly data sets at $550 \mathrm{~nm}$ archived at $1^{\circ} \times 1^{\circ}$ grid resolution for the period

94 2003-2016. The satellite products were downloaded from the NASA website

95 https://giovanni.gsfc.nasa.gov/giovanni/. The MISR non-spherical AOD fraction over the desert region is often referred to as the "fraction of the total AOD due to dust" (Marey et al., 2011). The

97 passively derived aerosol information from the MODIS sensors have been used in several studies 98 of aerosol and global aerosol distribution (e.g., Chin et al., 2002; Ichoku et al., 2004), radiative 99 forcing (Yu et al., 2004), and aerosol influences on regional climate (Vinoj et al., 2014). It has 100 been reported that MODIS Aqua dark blue AOD products generally provide better accuracy over 101 the AP (Butt et al., 2017). Satellite retrievals of dust aerosol composition over the AP are 102 generally complex due to the high reflectance (Misra et al., 2015), and therefore extensive 103 validation with ground-based observations is warranted. photometers and is universally regarded as a reliable ground-based aerosol monitoring system, which can be used to validate satellite retrieved products all over the globe (Safarpour et al., 107 2014; Belle and Liu, 2016; Wei and Sun, 2016). AERONET data is available at three levels: 108 Level 1.0 (unscreened), Level 1.5 (cloud screened) and Level 2.0 (quality assured) (Holben et al., 109 1998). Due to the paucity of ground-based measurements and the unavailability of longer records 110 for the AP, we considered Level 2.0 AERONET AOD from Solar village which spans a longer 111 period record consistent with satellite retrieval periods. This dataset was also used for the 112 validation of the satellite-retrieved products. We also utilized the multivariate ENSO index 113 (MEI), which provides a complete and flexible description of the ENSO 114 (http://www.esrl.noaa.gov/psd/ensp/mei; Wolterand Timlin, 2011), to investigate the role of 
115 tropical climate drivers on the AP aerosol variability. Circulation variables (zonal, meridional 116 and vertical winds), surface air temperature, and sea level pressure (SLP) were obtained from the 117 ERA-Interim data (Dee et al., 2011) available at $0.75^{\circ} \times 0.75^{\circ}$ horizontal resolution. The 118 validation of the satellite retrieved products with AERONET is presented in the following 119 section.

120

121

122 123

124

125 126 127 128 129 130

\section{AOD analysis}

In this section, we present the validation of the MODIS and the MISR retrievals against ground based AERONET observations at the Solar Village, Saudi Arabia for the period 20032012, followed by an analysis of the spatial variability of the AOD at seasonal and inter-annual time scales. Following Almazroui et al. (2013) and Athar (2015), we also consider the periods starting from November to April (June to September) as wet (dry) seasons in the following analysis.

\subsection{Validation of satellite retrieved AOD products using AERONET observations}

Aerosol retrieval algorithms from satellite measurements generally involve several assumptions, and thus their reliability should be evaluated before they are utilized for analysis (Hao et al., 2005). Several studies have used AERONET observations from the Solar Village to validate MISR, MODIS retrievals for shorter time periods over the AP (Yu et al. 2003; Martonchik et al. 2004; Kahn et al. 2005; Remer et al. 2008; Amanollahi et al. 2011; De Meij and Lelieveld, 2011). Here, we make use of the long-term data record available at the Solar Village, which almost completely coincides with the available satellite retrieval period.

Monthly means of AOD computed using hourly observations from the ground-based AERONET database are compared with the monthly MODIS and MISR data products. The monthly mean AOD differences between AERONET and the satellite observations for the period 
2003-2012 are shown in Figure 1a. Although the datasets are generally in close agreement, the MODIS data product is in better agreement with the AERONET data than the MISR data product. The annual cycle is comparable in all datasets (Fig.1b), although the MISR retrieved AODs exhibit significantly larger magnitudes during the dry season. For example, the monthly mean of the AERONET measured AODs at the Solar Village is 0.56 in May. This value is close to the MODIS AOD (0.51), compared to that of MISR (0.67). These minor differences are more evident in the correlations between the observed and the satellite retrievals, where the MODIS data is well correlated with AERONET (0.9), compared to the MISR data (0.7).

\subsection{Spatio-temporal variability of AOD from MODIS and MISR}

To synthesize the AOD variability, we divide the study region based on their variability (standard deviations) into three sub-regions: (i) land region over the North-East AP (NEAP; $24^{\circ} \mathrm{N}-32^{\circ} \mathrm{N}$ and $43^{\circ} \mathrm{E}-54^{\circ} \mathrm{E}$ ), (ii) Southern Red Sea region (SR; $13^{\circ} \mathrm{N}-20^{\circ} \mathrm{N}$ and $38^{\circ} \mathrm{E}-44^{\circ} \mathrm{E}$ ) and (iii) Northern Red Sea region (NR; $33^{\circ} \mathrm{E}-40^{\circ} \mathrm{E}$ and $20^{\circ} \mathrm{N}-29^{\circ} \mathrm{N}$ ) as shown in figure 4.

We first analyze the annual means together with the annual cycle from the satelliteretrieved datasets. Figure 2 plots the spatial distribution of the annual mean (Fig. 2a and 2b) and the annual cycle of the regionally averaged (encompassing the region covering $12^{\circ} \mathrm{N}-30^{\circ} \mathrm{N}$ and $30^{\circ} \mathrm{E}-60^{\circ} \mathrm{E}$ ) AOD (Fig. 2c) over the AP. High magnitudes of AODs are observed over the central and eastern AP, the SR, and northern Arabian Sea, while weaker magnitudes are noticeable over Sudan and the north-western part of the AP. The MODIS and MISR display similar spatial patterns with AODs are being smaller magnitudes $(<0.2)$ over the Oman mountains. The annual cycle of the AOD over the AP (Fig. 2c) indicates that the AOD falls (rises) to a minimum (maximum) during the wet (dry) seasons. In general, the MODIS and MISR display similar annual cycles of AOD, with a correlation coefficient (CC) of about 0.9. The AOD magnitudes 
generally start to increase from May and peaks in July with a mean value $0.57(0.56)$ and a standard deviation of about 0.08 (0.06) for MODIS (MISR).

The reanalyzed circulation patterns and spatial distribution of the AODs are shown in Figure 3 for the dry and wet seasons. The low-level winds display an anticyclonic circulation over the AP and the prevalence of the southerly winds over the Southern Red sea (SR) during the wet season, coinciding with lower AODs. The summertime circulation in the vicinity of the AP is typically composed of northerly winds in the northern AP and southwesterly winds from the Indian Ocean. During the dry season, the AP experiences strong northerly winds, which are associated with larger AODs. In addition, significantly high AODs of magnitude (0.5 to 0.7) are observed over the SR region and the regions extending from the northern Arabian Sea to the Arabian Gulf. The strong low-level northerly/northwesterly winds (Shamal winds) over the NEAP region tends to trigger dust saltation activity over the AP (Yu et al. 2013). It is also noted that strong westerly winds prevail over the Tokar Gap (Tokar Gap Jet; Jiang et al. 2009; Davis et al. 2015) during the summer, which also contribute to the high amount of AOD. Overall AOD displays prominent signatures of seasonality over the AP that is consistent with ambient circulation patterns.

Figure 4 shows the spatial distribution of the standard deviations of the AOD for the period 2003-2016 from MODIS and MISR, for the dry and wet seasons over the AP and the adjoining oceans. A high variability of the AODs is clear during the dry season compared to the wet season. The standard deviations of the AODs are seen to be larger over the region extending from the central to the eastern AP, and also over the SR. Smaller deviations were observed over the northwestern part of the AP and Sudan. MODIS and MISR generally display similar patterns, with smaller AODs over the Oman Mountains (less than 0.1) and significantly larger values over 
184 the northern part of the Arabian Sea. MODIS (MISR) data also displays larger (smaller) standard 185 deviations over the Arabian Gulf region. The variability is less than 0.04 over the NEAP region 186 during the wet season, while the variability of the AOD is large over the SR and the NEAP 187 during dry conditions.

Figure 5 plots the spatially averaged time series of the AODs for the sub regional northeastern part of the AP, NEAP, SR and NR. The results clearly indicate that the variability 190 over these regions at different time scales are generally consistent in both satellite products. A 191 clear distinction between the AODs over the northern and southern regions is visible, with higher 192 AODs over the SR and remaining parts of the AP, and weaker AODs over the NR and NEAP. 193 Figures 5(a-d) display the time series for these sub-regions for the 2003-2016 period. The AOD 194 magnitudes inferred by the MISR and MODIS data during the wet season are reduced (below 195 0.3), while the maximum AODs are observed during the dry season over the eastern part of the 196 AP and SR. The mean, standard deviations (SD) and the coefficient of variability (CV) of the 197 AOD over the aforementioned regions are shown in Table 1. Higher mean values (0.67/0.64) and SDs (0.08/0.08) are seen for both MISR/MODIS data during the dry season, while the mean 199 value is $0.31 / 0.28$ and the SD is $0.04 / 0.03$ for the wet season. An overall analysis of the spatial 200 patterns at annual and seasonal scales along with the annual cycle of the AOD over the AP 201 essentially indicates similar features from both the MISR and MODIS datasets. 204 indicate maximum correlations of 0.85 and 0.75 with AERONET over the AP region for the dry 205 season. The MODIS and MISR suggest maximum correlations of 0.8 and 0.7 during the wet 206 season, respectively. In addition, the deviations from the least-square fit line is lower for 
MODIS. Although less in number, the deviation of high values from the observed values would

208 also contribute more to the scatter. Despite the stronger correlation, MODIS data is generally in

209 better agreement with the ground-based observations than the MISR data product on a seasonal

210 scale. This analysis is corroborated by earlier studies by Butt et al. (2017), which suggests that

211 the MODIS AOD is well suited to represent aerosol concentrations over warm surfaces and the

212 AOD variability over the AP.

\section{$213 \quad 3.3$ Interannual variability of AOD}

Figure 7 outlines the inter-annual variations of the AOD during the period $2003-2016$

215 over the AP, NEAP, SR and NR regions. The AOD anomalies were computed by removing the

216 means of the dry and wet seasons. The AOD exhibits year-to-year variations in all sub-regions of

217 the AP during the dry and wet seasons. Negative AOD anomalies are noticeable all over the AP

218 during all seasons from 2003 to 2007, followed by positive anomalies. These year-to-year

219 variations of the AOD are significantly higher during the dry seasons (Coefficient of Variability

220 (CV) 15.9\%) than during the wet seasons (CV 12.9\%). These changes are generally associated

221 with year-to-year variations in the aerosol (AOD) loading and this phenomenon needs to be

222 further analyzed with respect to the variations of large scale flow patterns and their related

223 climate drivers. We consider the ENSO to assess the changes in large scale circulations and

224 associated aerosol loading as one of the highly studied climate drivers over the AP region.

225

The ENSO phenomenon is a potential tipping element for the inter-annual variability of

226 regional climate (e.g., Raitsos et al., 2015; Dasari et al., 2017; Attada et al., 2018). In this study,

227 we assess the role of the ENSO on the AOD variability over the AP during the dry season.

228 Higher contributions of dust loading suggest the summer as an obvious choice for this purpose.

229 The correlations between the monthly MEI index and the AOD anomalies (Fig. 8) show a 
230 significant negative correlation of -0.35 at the $95 \%$ confidence level. This indicates that the 231 positive phase of the ENSO (El Niño) contributes to smaller AOD variability over the AP region, 232 while the negative phase of the ENSO (La Niña) contributes to a larger AOD variability. We 233 further conducted a composite analysis for the El Niño $(2004,2009,2015)$ and La Niña (2008, $2342010,2011)$ years and presented the results in Figure 9. The spatial distribution of the AOD and 235 the low-level $(850 \mathrm{hPa})$ winds during the El Niño (Fig. 9a) and La Niña (Fig. 9b) conditions are 236 presented. While we agree that the limited number of years constrains any definite results, the 237 composite analysis provides an indication of the major changes in the atmospheric conditions 238 that can create significant year-to-year variations in the AODs over the AP. The AOD 239 distributions are much larger in magnitudes (greater than 0.6) over the eastern AP, SR and the 240 Northern Arabian Sea during the La Niña phase. The composite differences (Fig. 9c) show a 241 prevalence of northerly winds over the entire AP, and a strong Tokar jet over the west coast of 242 the Red Sea. This suggests that the low-level intensified Tokar gap jet during the La Niña phase 243 tends to advect the aerosol concentrations from East Africa, resulting in higher AODs over the 244 AP. Hickey and Goudie (2007) also reported that the Tokar Gap region is one of two major 245 source regions for dust storms. Another interesting feature is the aerosol uplift, which was 246 favored by the intensified shallow cyclonic circulation over the AP, and the associated wind 247 convergence during the La Niña phase. Although the Shamal winds appeared to weaken during 248 the La Niña phase, higher AODs (Fig. 9b) were mainly due to the Tokar Gap jet, while the 249 locally induced AODs over the AP resulted from the thermal convection. Overall, the southern 250 AP shows a significantly larger AOD than the northern AP and the northern RS regions during 251 La Niña period. The mean values of the AOD during these two phases for different regions are 252 shown in Table 2. It can be clearly seen that the mean AOD is larger by approximately 0.65 
253 compared to the SR. Moreover, the mean value is significantly higher during the La Niña (0.72)

254 phase and lower during the El Niño (0.63) phase. However, the relative difference is found to be 255 higher by about $15 \%$ over the NEAP region.

256 The zonal mean (averaged over longitudes between $35^{\circ} \mathrm{E}$ and $60^{\circ} \mathrm{E}$ ) of the AOD during 257 the El Niño and La Niña phases clearly shows a latitudinal variation over the AP. Essentially, 258 larger AODs are noticed at $19^{\circ} \mathrm{N}$, which can be attributed to the presence of the Tokar gap jet. 259 Smaller AODs are observed north of $28^{\circ} \mathrm{N}$ and this value tends to be higher during the La Niña 260 phase compared to El Niño phase. On the other hand, the meridional distribution of the AOD is 261 smaller than the mean during the El Niño phase. This suggests a potential effect of the ENSO on 262 the AOD changes over the AP. This is particularly important for the larger AODs during the La 263 Niña phase. To further understand this variability, a composite analysis of temperature, sea level 264 pressure (SLP), vertical velocities and radiation was performed. Figure 11(a-c) shows the spatial 265 distributions of the vertical velocities at $500 \mathrm{hPa}$ during the El Niño and La Niña phases. The 266 composite difference in the vertical velocities between the two phases suggest high vertical 267 motion prevailed over the southwestern and Eastern AP. This strong ascent, triggered by thermal 268 convection, uplifts dust particles. The SLP distribution shown in Figure 11(d-f) reveals the 269 monsoon associated low-pressure over the Arabian Gulf, and high-pressure system over the 270 North of the AP during both the El Niño and La Niña periods. The thermal low is enhanced 271 during the La Niña period compared to the El Niño phase, which suggests that the La Niña 272 conditions cause an intensification of the low-pressure system over the AP.

273 The composite analysis of the surface temperature (at $2 \mathrm{~m}$ height) plotted in Figure 12 (a274 c) shows lower temperatures over the southwestern parts of the AP and increased temperatures 275 over the Eastern and central AP during the El Niño and the La Niña periods. The composite 
276 difference of the $2 \mathrm{~m}$ air temperatures (Fig. 12c) between the La Niña and El Niño phases

277 indicate high temperatures over the eastern AP, north and northeastern AP, in addition to low 278 temperatures over the southwestern AP and Sudan. Therefore, La Niña enforces higher 279 temperatures over the eastern AP. The total shortwave radiation composites during the La Niña, 280 El Niño, and the difference between the two (Figure 12(d-f)), also indicate the presence of 281 significantly high shortwave radiation over the Red Sea, Arabian Gulf and Arabian Sea (above

$282330 \mathrm{~W} \mathrm{~m}^{-2}$ ) during the La Niña phase. Over the AP, the radiation level is approximately 280

$283 \mathrm{Wm}^{-2}$, but the composite difference in the shortwave radiation indicated higher levels over the 284 AP, Arabian Gulf and Iran region during La Niña phases compared to El Niño phases. Our 285 analysis reveals that the enhanced AODs are due to the cool tropical eastern Pacific sea surface 286 temperature (La Niña). This suggests that the negative phase of the ENSO (i.e. La Niña) is an 287 important contributor of the interannual variability of the AOD over the AP region during 288 summer.

\section{$289 \quad 3.4$ Synthesis of physical processes}

The previous section highlighted significant impact of the ENSO on the interannual 291 variability of the AOD over the eastern and northeast AP and the SR regions, particularly during 292 the La Niña periods, which exhibit higher (positive anomalies) AOD. Higher amounts of AOD 293 over the SR and the southwestern AP are attributed to the intensification of the Tokar Gap jet. 294 This was due to steep pressure gradients, which favored Saharan dust transport through the East 295 Africa region to the southern Red Sea. Higher AOD over the NEAP, and the eastern AP are due 296 to locally induced AOD from the desert, which occurs in conjunction with the vertical velocities 297 and the SLP, as previously discussed. Interestingly, the Shamal winds are weaker over the 298 NEAP, but exhibit higher AODs during the La Niña phase because of the locally induced dust 
that dominates over this region. The intensified shallow low-pressure system during La Niña

300 triggers the regional convergence of winds and the associated ascent, which enhances the AOD

301 in the lower troposphere. The mid-tropospheric anticyclone distributes the suspended AOD

302 towards the NEAP region, which results in higher AOD values. In addition, the AOD absorbs the

303 radiation and warms the atmosphere over the NEAP. This is reflected by the shortwave radiation

304 and surface temperature values. Furthermore, the southwestern AP exhibits a much lower AOD

305 during La Niña, which is attributed to the wet scavenging mechanisms (Pandey et al., 2017).

306

307

308

309

310

311

312

313

314

315

316

317

318

\section{Summary and Discussions}

This study investigated the Aerosols Optical Depth (AOD) variability over the Arabian Peninsula (AP) at seasonal and interannual time scales and also studied the influence of large scale climate drivers such as ENSO on the AOD variability using the ground-based measurements (AERONET: for the period 2003-2012) and satellite observations (MODIS and MISR: for the period 2003-2016). A strong correlation of $0.85(0.81)$ between the MODIS and AERONET observations was obtained for the dry (wet) period. Higher AODs are typically observed over the regions of the eastern AP, northeast AP (NEAP) and Southern Red Sea (SR) regions during the dry season. The spatial distribution of AOD was generally consistent and similar in both MODIS and MISR products, and indicates larger (weaker) AOD magnitudes over the central and eastern regions of the AP and over SR, northeast regions of the AP and Sudan. The AOD is much weaker $(<0.3)$ during the wet period, while a large variability is observed during the dry season.

The results are also suggested that the ENSO phenomenon has a negative relationship (correlations of -0.35 at $95 \%$ significance level) with AOD variations. In particular, the negative phase of the ENSO (La Niña) tends to favor enhanced AODs over the AP. Positive AOD 
anomalies tend to prevail during the La Niña phases in association with higher AODs over the eastern AP, northeast AP and SR regions. Higher AODs are primarily due to the intensified Tokar jet resulting from the strong pressure gradient arising from the thermal contrast between the Red Sea and the interior Sudanese land mass. This facilitates the advection of aerosol concentration to the western shore of the Red Sea and over the AP. Larger AODs over the northeastern AP and eastern AP are locally induced from the desert during La Niña periods. It is also interesting to note that higher AODs values are noticed over the eastern regions of the AP, despite the weaker Shamal winds (important regulators of summer dust activity) over the northeast AP. Our analysis also indicates that the intensified shallow low pressure system during the La Nina phases shows a tendency to trigger the local convergence and associated updrafts. This favors lifting of the aerosols into the lower troposphere where the mid-tropospheric anticyclone supports the suspended aerosols more towards the northeast AP, resulting in higher AOD during the La Niña than El Niño phases. Furthermore, the aerosols absorb short wave radiation leads to warmer atmospheric conditions over the northeastern AP and eastern AP. The significant amounts of orographic induced rainfall over southwestern AP leads to smaller AOD due to the rain washout mechanism during the La Niña phases. This study also indicates that higher AODs over the AP region are not associated with the northerly winds, but resulting are frequently from mesoscale unstable weather systems, which advect the dust from the dry regions to the eastern deserts of the AP.

In summary, the La Niña phase of the ENSO cycle (the cold phase) favors rising frequency of dust storms over the AP region, which is supported by positive anomalies over the AP. However, during the El Niño phase (the warm phase) the opposite effect prevails. The increased surface temperatures generally enhance the soil dryness and dust entrainment during 
345 the La Nina phase, whereas opposite conditions prevail during the El Niño phase. During the 346 summer associated with the La Niña phase, the lower geopotential heights over the AP favors the 347 required horizontal gradient for dust transportation from the surrounding regions. These 348 conditions also intensifies of north-westerly and north-easterly winds, and the Tokar jet which 349 leads to enhanced dust transportation over the AP. Therefore, dry conditions during the La Niña 350 phase are favorable to subsequent increased soil dryness (less soil moisture and more soil 351 temperature) and thereby enhancing dust activity over the region. This study provides new 352 insights into the physical mechanisms associated with the variability of the AOD during the 353 ENSO episodes. In addition, it also serves as a roadmap towards understanding the spatial and 354 temporal distribution of dust variations over the AP.

\section{Acknowledgements}

357 The reported research was supported by funding from King Abdullah University of Science and 358 Technology (KAUST) and the General Commission for Survey (GCS) under Award Number $359 \mathrm{RGC/3/1612-01-0.} \mathrm{The} \mathrm{authors} \mathrm{extend} \mathrm{their} \mathrm{gratitude} \mathrm{to} \mathrm{the} \mathrm{AERONET} \mathrm{team} \mathrm{for} \mathrm{making} \mathrm{their}$ 360 data available for this study. 


\section{References}

367 Abdi Vishkaee F., Flamant, C., Cuesta, J., Oolman, L., Flamant, P. and Khalesifard, H, R. 368 (2012), Dust transport over Iraq and northwest Iran associated with winter Shamal: a case study. 369 J. Geophys. Res. 117(d03201):14. doi: 10.1029/2011jd016339.

370 Alharbi, B. H. (2009), Airborne Dust in Saudi Arabia: Source Areas, Entrainment, Simulation 371 and Composition. Ph.D. Thesis. Monash University, Monash, Australia, p. 345.

372 Alharbi, B. H., Maghrabi, A. and Tapper, N. (2013), The march 2009 dust event in Saudi Arabia: 373 precursor and supportive environment. B. Am. Meteorol. Soc., 94, 515-528, 2013.

374 Almazroui, M., Abid, M. A., Athar, H., Islam, M. N. and Ehsan, M. A. (2013), Interannual 375 variability of rainfall over the Arabian Peninsula using the IPCC AR4 Global Climate Models. 376 Int. J. Climatol., 33: 2328-2340. doi:10.1002/joc.3600. assessment of moderate resolution image spectroradiometer products for dust storms in semiarid environment. Int. J. Environ. Sci. Technol., 8(2), 373-380.

Athar, H. (2015), Teleconnections and variability in observed rainfall over Saudi Arabia during 1978-2010. Atmos. Sci. Let. 16 : 373-379 (2015), doi: 10.1002/as12.570.

Attada, R., Dasari, H.P., Chowdary, J.S., Yadav, R.K., Knio, O. and Hoteit, I. (2018), Surface Air Temperature Variability over the Arabian Peninsula during the Twentieth Century and their links to Circulation Patterns. Int. J. of Clim. (Under review).

Belle, J.H. and Liu, Y. (2016), Evaluation of Aqua MODIS collection 6 AOD parameters for air quality research over the continental United States. Remote Sens. 8 (815), 1-14. http://dx.doi.org/10.3390/rs8100815.

Butt, M.J., Assiri, M.E. and Ali., M.A. (2017), Assessment of AOD variability over Saudi Arabia using MODIS Deep Blue products. Environmental Pollution., 231 (2017) 143-153, http://dx.doi.org/10.1016/j.envpol.2017.07.104

Charlson, R.J., Schwartz, S.E., Hales, J.M., Cess, R.D., Coakley Jr., J.A., Hansen, J.J.E. and Hofmann, D.J. (1992), Climate forcing by anthropogenic aerosols. Science, 255: 423- 430.

Chin M, Ginoux P, Kinne S, Torres O, Holben B.N. and Duncan B.N. (2002), Tropospheric aerosol optical thickness from the GOCART model and comparisons with satellite and sun photometer measurements. J. Atm. Sci., 59:461-483.10.1175/1520-0469(2002)059 $<0461$ :TAOTFT>2.0.CO;2

397 Dasari, H. P., Langodan, S., Viswanadhapalli, Y., Vadlamudi, B. R., Papadopoulos, V. P. and 398 Hoteit, I. (2017), ENSO influence on the interannual variability of the Red Sea convergence 399 zone and associated rainfall. Int. J. Clim., doi:10.1002/joc.5208 
Davis, S.R., Pratt, L. J. and Jiang, H. (2015), The Tokar Gap jet: Regional circulation, diurnal variability, and moisture transport based on numerical simulations. J. Clim., 28, 58855907,doi:10.1175/JCLI-D-14-00635.1.

Dee, D. P., Uppala, S. M., Simmons, A. J., Berrisford, P., Poli, P., Kobayashi, S., Andrae, U. and Balmaseda, M.A. et al. (2011), The ERA-Interim reanalysis: configuration and performance of the data assimilation system. Q. J. R. Meteorol. Soc., 137: 553-597. doi:10.1002/qj.828.

De Meij, A. and Lelieveld, J. (2011), Evaluating aerosol optical properties observed by groundbased and satellite remote sensing over the Mediterranean and the Middle East in 2006. Atmos. Res., 99, 415-433.

Diner, D.J., Beckert, J.C, Reilly, T.H., Bruegge, C.J., Conel, J.E.,Kahn, R.A., Martonchik, J.V., Ackerman, T.P., Davies, R., Gerstl, S.A.W., Gordon, H.R., Muller, J.P., Myneni, R.B., Sellers, P.J., Pinty, B. and Michel M. (1998), Multi-angle Imaging SpectroRadiometer (MISR) instrument description and experiment overview. IEEE Trans. Geosci. Rem. Sens., 36, 10721087,1998 .

Engelstaedter, S., Tegen, I. and Washington, R. (2006), North African dust emissions and transport. Earth-Science Reviews 79 (1-2), 73-100.

Farahat, A., El-Askary, H. and Al-Shaibani, A. (2015), Study of aerosols characteristics and dynamics over the kingdom of Saudi Arabia using a multisensor approach combined with ground observations. Adv. Meteorology, http://dx.doi.org/ 10.1155/2015/247531.

Ginoux, P.A., Prospero, J.M., Gill, T.E., Hsu, C. and Zhao, M. (2012), Global-scale attribution of anthropogenic and natural dust sources and their emission rates based on MODIS Deep Blue aerosol products. Rev. Geophys. 50, RG3005. http://dx.doi.org/10.1029/2012RG000388.

Goudie, A.S. and Middleton, N. J. (2006), Desert Dust in the Global System. Springer, Heidelberg, Germany.

Hao, W. M., Ward, D. E., Susott, R. A., Babbitt, R. E., Nordgren, B. L., Kaufman, Y. J., Holben, B.N. and Giles, D. M. (2005), Comparison of aerosol optical thickness measurements by MODIS, AERONET sun photometers, and Forest Service handheld sun photometers in southern Africa during the SAFARI 2000 campaign. Int. J. Remote Sens.,26, 4169-4183.

Hickey, B. and Goudie, A. S. (2007), The use of TOMS and MODIS to identify dust storm source areas: The Tokar delta (Sudan) and the Seistan basin (south west Asia), in Geomorphological Variations, edited by A. S.Goudie and J. Kalvoda, pp. 37-57, P3K, Prague.

Holben, B.N., Eck, T.F., Slutsker, I., Tanré, D., Buis, J. P., Setzer, A., Vermote, E., Reagan, J. A., Kaufman,Y. J., Nakajima, T., F.Lavenu, F., Jankowiak, I. and Smirnov, A. (1998), AERONET A federated Instrument network and data archive for aerosol characterization. Remote Sens. Environ., 66, 1-16, 1998. 
Ichoku, C., Chu, D. A., Mattoo, S., Kaufman, Y. J., Remer, L. A., Tanré, D., Slutsker, I. and Holben, B. N. (2002), A spatio-temporal approach for global validation and analysis of MODIS aerosol products, Geophys. Res. Lett. 29, 8006.

Ichoku, C., Kaufman, Y. J., Remer, L. A. and Levy, R. (2004), Global aerosol remote sensing from MODIS. Adv. Space Res. 34, 820-827.

IPCC: Climate Change 2013: The Physical Basis. Contribution of Working Group I to the Fifth Assessment Report of the Intergovernmental Panel on Climate Change, edited by: Cambridge University Press, Cambridge, United Kingdom and New York, USA, 1535 pp., 2013.

Israelevich, P., Ganor, E., Alpert, P., Kishcha, P. and Stupp, A. (2012), Predominant transport paths of Saharan dust over the Mediterranean Sea to Europe. J. Geophys.Res. 117:D02205.

Jiang, H., Farrar, J. T., Beardsley, R. C., Chen, R. and Chen, C. (2009), Zonal surface wind jets across the Red Sea due to mountain gap forcing along both sides of the Red Sea. Geophys. Res. Lett., 36, L19605, doi:10.1029/2009GL040008.

Kaskaoutis,D.G., Gautam, R., Sing, P., Houssos, E., Goto, D., Singh, S., Bartzokas, A., Kosmopoulos, P. G., Sharma, M., Hsu, N. C., Holben, B. N. and Takemura, T. (2012), Influence of anomalous dry conditions on aerosols over India: transport, distribution and properties. J. Geophys. Res. 117:D09106. doi:10.1029/2011JD017314.

Kaufman, Y.J., Tanre, D., Remer, L. A., Vermote, E. F., Chu, A. and Holben, B. N. (1997), Operational remote sensing of tropospheric aerosol over land from EOS moderate resolution imaging spectroradiometer. J. Geophys. Res. 102, 17051.

Kaufman, Y. J., Tanre, D. and Boucher, O. (2002), A satellite view of aerosols in the climate system. Nature 419: 215-223.

Kahn, R. A., Gaitley, B. J., Martonchik, J. V., Diner, D. J. and Crean, K. A. (2005), Multiangle Imaging Spectroradiometer (MISR) global aerosol optical depth validation based on 2 years of coincident Aerosol Robotic Network (AERONET) observations. J. Geophys. Res., 110, D10S04, doi:10.1029/2004JD004706.

Kolhe, A.R., Pawar, G.V., Varpe, S. R., Kumar, P.P., Devara, P.C.S. and Aher, G. R. (2016), Multi-year analysis of aerosol properties retrieved from the Ångström parameters for different spectral ranges over Pune. Aerosol Air Qual. Res. 16: 3266-3280.

Kosmopoulos, P.G., Kaskaoutis, D.G., Nastos, P.T. and Kambezidis, H.D. (2008), Seasonal variation of columnar aerosol optical properties over Athens, Greece, based on MODIS data. Remote Sens. Environ. 112: 2354- 2366.

Levy, R. C., Remer, L. A., Mattoo, S., Vermote, E. F. and Kaufman, Y. J. (2007), Secondgeneration operational algorithm: retrieval of aerosol properties over land from inversion of moderate resolution imaging spectroradiometer spectral reflectance. J. Geophys. Res. 112, 13211. 
471 Levy, R. C., Remer, L. A., Kleidman, R. G., Mattoo, S., Ichoku, C., Kahn, R. and Eck, T. F. 472 (2010), Global evaluation of the collection 5 MODIS dark-target aerosol products over land. 473 Atmos. Chem. Phys. 10, 10399-10420.

474 Liu, Z., Liu, D. and Huang, J. (2008), Airborne dust distributions over the Tibetan Plateau and 475 surrounding areas derived from the first year of CALIPSO lidar observations. Atmos. Chem. 476 Phys. Discuss. 8:5957-5977.

477 Lohmann, U. and Feichter, J. (2005), Global indirect aerosol effects: A review. Atmos. Chem.

478 Phys. 5: 715-737.

479 Misra, A., Jayaraman, A. and Ganguly, D. (2015), Validation of version 5.1 MODIS aerosol 480 optical depth (Deep blue algorithm and Dark target approach) over a semi-arid location in 481 western India. Aerosol Air Qual. Res. 15, 252-262

482 Marey, H. S., Gille, J.C., El-Askary, H. M., Shalaby, E. A. and El-Raey, M. E. (2011), Aerosol 483 climatology over Nile Delta based on MODIS, MISR and OMI satellite data. Atmos. Chem. 484 Phys. 11, 10637-10648, https://doi.org/10.5194/acp-11-10637-2011, 2011.

485 Martonchik, J. V., Diner, D. J., Kahn, R., Gaitley, B. and Holben, B. N. (2004), Comparison of 486 MISR and AERONET aerosol optical depths over desert sites. Geophys. Res. Lett., 31, 487 L16102,doi:10.1029/2004GL019807.

488 Maghrabi, A., Alharbi, B. and Tapper, N. (2011), Impact of the March 2009 dust event in Saudi 489 Arabia on aerosol optical properties, meteorological parameters, sky temperature and emissivity. 490 Atmos. Environ., 45 (13), 2164-2173.

491 Maghrabi, A.H. and Alotaibi, R.N. (2017), Long-term variations of AOD from an AERONET 492 station in the central Arabian Peninsula. Theo. Applied Climatology, 493 https://doi.org/10.1007/s00704-017-2328.

494 Mashat, A. S., Alamodi, A. O. and Ahmed, H. A. M. (2008), Diagnostic and prognostic study for 495 dust (sand) storms over Saudi Arabia, Tech. Rep. V18_AR-26-89, King Abdulaziz University, 496 Faculty of Meteorology, Environment and Arid Land Agriculture, Saudi Arabia, 2008.

497 Nafiseh, E., Marjan, G., Abbas, R. and Gabriele, G. (2014), Dust events, pulmonary diseases and 498 immune system. Am. J. Clin. Exp. Immunol, 3, 20-29.

499 Pandey, S., Vinoj V., Landu, K. and Sureshbabu, S (2017), Declining pre-monsoon dust loading 500 over South Asia: Signature of a changing regional climate. Scientific Reports 7, Article number: 50116062 (2017):10.1038/s41598-017-16338-w

502 Papadimas, C.D., Hatzianastassiou, N., Mihaloppoulos, N., Kanakidou, M., Katsoulis, B.D. and 503 Vardavas, I. (2008), Assessment of the MODIS collections C005 and C004 aerosol optical depth 504 products over the Mediterranean basin. Atmos. Chem. Phys. 9: 2987- 2999.

505 Pawar, G.V., Devara, P.C.S. and Aher, G.R. (2015), Identification of aerosol types over an 506 urban site based on air-mass trajectory classification. Atmos. Res. 164-165: 142-155. 
Raitsos, D. E., Hoteit, I., Prihartato, P. K., Chronis, T., Triantafyllou, G. and Abualnaja, Y. (2011), Abrupt warming of the Red Sea. Geophys. Res. Lett., 38, L14601, doi:10.1029/2011GL047984.

Ramanathan, V., Crutzen, P.J., Kiehl, J.T. and Rosenfeld, D. (2001), Aerosol, climate, and hydrological cycle. Science 294: 2119-2124.

Remer, L. A., Kleidman, R.G., Levy , R.C., Kaufman, Y.J., Tanré, D., Mattoo, S., Martins, J.V., Ichoku, C., Koren, I., Yu, H. and Holben, B.N. (2008), Global aerosol climatology from the MODIS satellite sensors. J. Geophys. Res., 113, D14S07, doi:10.1029/2007JD009661.

Safarpour, S., Abdullah, K., Lim, H.S. and Dadras, M. (2014), Accuracy assessment of terra MODIS aerosol optical depth retrievals, In: Proc.7th IGRSM International Remote Sensing \& GIS Conference and Exhibition. http://dx.doi.org/10.1088/ 1755-1315/20/1/012059 kuala Lumpur, Malaysia, 2014, E. Einv. Sci. 20: 012059.

Sannazzaro, F., Filizzola, C., Marchese, F., Corrado, R., Paciello, R., Mazzeo, G., Pergola, N. and Tramutoli, V. (2014), Identification of dust outbreaks on infrared MSG-SEVIRI data by using a Robust Satellite Technique (RST), Acta Astronaut. 93, 64-70.

Schepanski, K., Tegen, I. and Macke, A. (2012), Comparison of satellite based observations of Saharan dust source areas. Remote Sens. Environ. 123, 90-97.

Schmetz, J., Pili, P., Tjemkes, S., Just, D., Kerkmann, J., Rota, S. and Ratier, A. (2002), An introduction to meteosat second generation (MSG). Bull. Am. Meteorol. Soc. 83, 977-992.

Shalaby, A., Rappenglueck, B. and Eltahir, E. A. B. (2015), The climatology of dust aerosol over the Arabian peninsula. Atmos. Chem. Phys. Discuss. 15, 1523-1571.

Sultan, A. M., Al-Kheraiji, M. F., Ziyad, F.A., Nasser, A. A. and Ahmad, A. A. (2013), Respiratory and general health complaints in subjects exposed to sandstorm at Riyadh, Saudi Arabia. Pak J. Med. Sci. 29, 642-646.

Tanaka, T.Y. and Chiba, M., (2006), A numerical study of the contributions of dust source regions to the global dust budget. Glob. Planet. Change 52, 88-104.

Tanre, D., Kaufman, Y. J., Herman, M. and Mattoo, S. (1997), Remote sensing of aerosol properties over oceans using the MODIS/EOS spectral radiances. J. Geophys. Res. 102, 16971

Tindale, N.W. and Pease, P.P. (1999), Aerosols over the Arabian Sea: atmospheric transport pathways and concentrations of dust and sea salt. Deep-Sea Res. II 46, 1577-1595.

Vinoj, V., Rasch, P. J., Wang, H., Yoon, J. H., Ma, P. L., Landu, K. and Singh, B. (2014), Shortterm modulation of Indian summer monsoon rainfall by West Asian dust. Nat. Geosci. 7, 308313.

Wei, J. and Sun, L. (2016), Comparison and evaluation of different MODIS aerosol optical depth products over the beijing-tianjin-hebei region in China. IEEE J. Sel. Top. Appl. Earth Observations Remote Sens. (99), 1e10. http://dx.doi.org/10.1109/ JSTARS.2016.2595624. 
543 Wolter, K. and Timlin, M. S. (2011), El Niño/Southern Oscillation behavior since 1871 as

544 diagnosed in an extended multivariate ENSO index (MEI. ext). Int. J. Clim.31, 1074-1087

545 Xian, G.Z. (2016), Remote Sensing Applications for the Urban Environment. CRC Press, Boca 546 Raton, London, New York.

547 Yu, H., Dickinson, R. E., Chin, M., Kaufman, Y. J., Holben, B. N., Geogdzhayev, I. V. and. 548 Mishchenko, M.I. (2003), Annual cycle of global distributions of aerosol optical depth from 549 integration of MODIS retrievals and GOCART model simulations. J. Geophys. Res., 108(D3), 550 4128, doi:10.1029/2002JD002717.

551 Yu, H., Dickinson, R. E., Chin, M., Kaufman, Y. J., Zhou, M., Zhou, L., Tian, Y., Dubovik, O. 552 and Holben, B.N. (2004), The direct radiative effect of aerosols as determined from a 553 combination of MODIS retrievals and GOCART simulations. J. Geophys. Res.,109, D03206, 554 doi:10.1029/2003JD003914.

555 Yu, Y., Notaro, M., Liu, Z., Kalashnikova, O., Alkolibi, F., Fadda, E. and Bakhrjy, F (2013), 556 Assessing temporal and spatial variations in atmospheric dust over Saudi Arabia through 557 satellite, radiometric, and station data. J. Geophys. Res.-Atmos., 118, 13253-13264, 558 doi:10.1002/2013JD020677.

559

560

561

562

563

564

565

566

567

568

569

570

571

572

573

574

575 
$\underline{\text { List of Tables }}$

\begin{tabular}{|c|c|c|c|c|c|c|c|c|}
\hline & \multicolumn{4}{|c|}{ Mean Values } & \multicolumn{4}{|c|}{$\mathrm{SD}(\mathrm{CV})$} \\
\hline & \multicolumn{2}{|c|}{ Dry Season } & \multicolumn{2}{|c|}{ Wet Season } & \multicolumn{2}{|c|}{ Dry Season } & \multicolumn{2}{|l|}{ Wet Season } \\
\hline & MISR & MODIS & MISR & MODIS & MISR & MODIS & MISR & MODIS \\
\hline SR & 0.676 & 0.645 & 0.314 & 0.281 & $\begin{array}{l}0.089 \\
(13.1)\end{array}$ & $\begin{array}{c}0.083 \\
(12.8)\end{array}$ & $\begin{array}{c}0.044 \\
(14.1)\end{array}$ & $\begin{array}{l}0.032 \\
(11.3)\end{array}$ \\
\hline NR & 0.393 & 0.345 & 0.235 & 0.221 & $\begin{array}{c}0.058 \\
(14.7)\end{array}$ & $\begin{array}{c}0.042 \\
(16.8)\end{array}$ & $\begin{array}{c}0.028 \\
(11.9)\end{array}$ & $\begin{array}{c}0.023 \\
(10.4)\end{array}$ \\
\hline NEAP & 0.477 & 0.408 & 0.308 & 0.338 & $\begin{array}{c}0.073 \\
(15.3)\end{array}$ & $\begin{array}{c}0.075 \\
(18.4)\end{array}$ & $\begin{array}{c}0.048 \\
(15.9)\end{array}$ & $\begin{array}{l}0.055 \\
(16.3)\end{array}$ \\
\hline AP & 0.516 & 0.446 & 0.274 & 0.255 & $\begin{array}{c}0.071 \\
(13.8)\end{array}$ & $\begin{array}{c}0.061 \\
(15.9)\end{array}$ & $\begin{array}{r}0.038 \\
(13.9)\end{array}$ & $\begin{array}{c}0.033 \\
(12.9)\end{array}$ \\
\hline
\end{tabular}

Table 1. presents the mean, standard deviations (SD) and coefficient of variability (CV) over different region of the Arabian Peninsula for different (dry and wet) seasons.

\begin{tabular}{|l|c|c|c|c|c|}
\hline & Mean & La Nina & El Nino & Diff & Rel. Diff (\%) \\
\hline SR & 0.645 & 0.722 & 0.629 & 0.093 & 12.88 \\
\hline NR & 0.345 & 0.379 & 0.351 & 0.028 & 7.38 \\
\hline NEAP & 0.405 & 0.483 & 0.409 & 0.074 & 15.32 \\
\hline AP & 0.444 & 0.503 & 0.433 & 0.07 & 13.91 \\
\hline
\end{tabular}

585

Table 2: Mean values of El Nino, La Nina and the difference between La Nina and El Nino. 
$\underline{\text { List of figures }}$

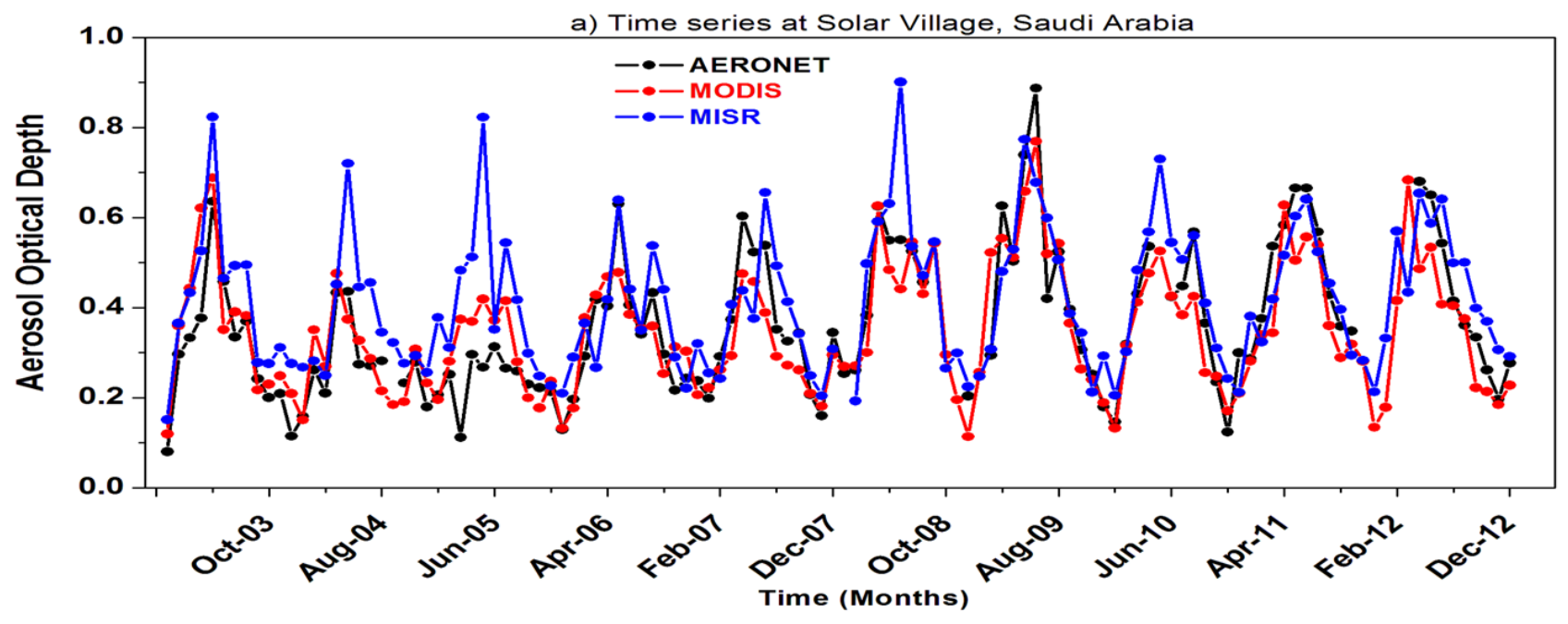

b) Annual cycle at Solar Village, Saudi Arabia

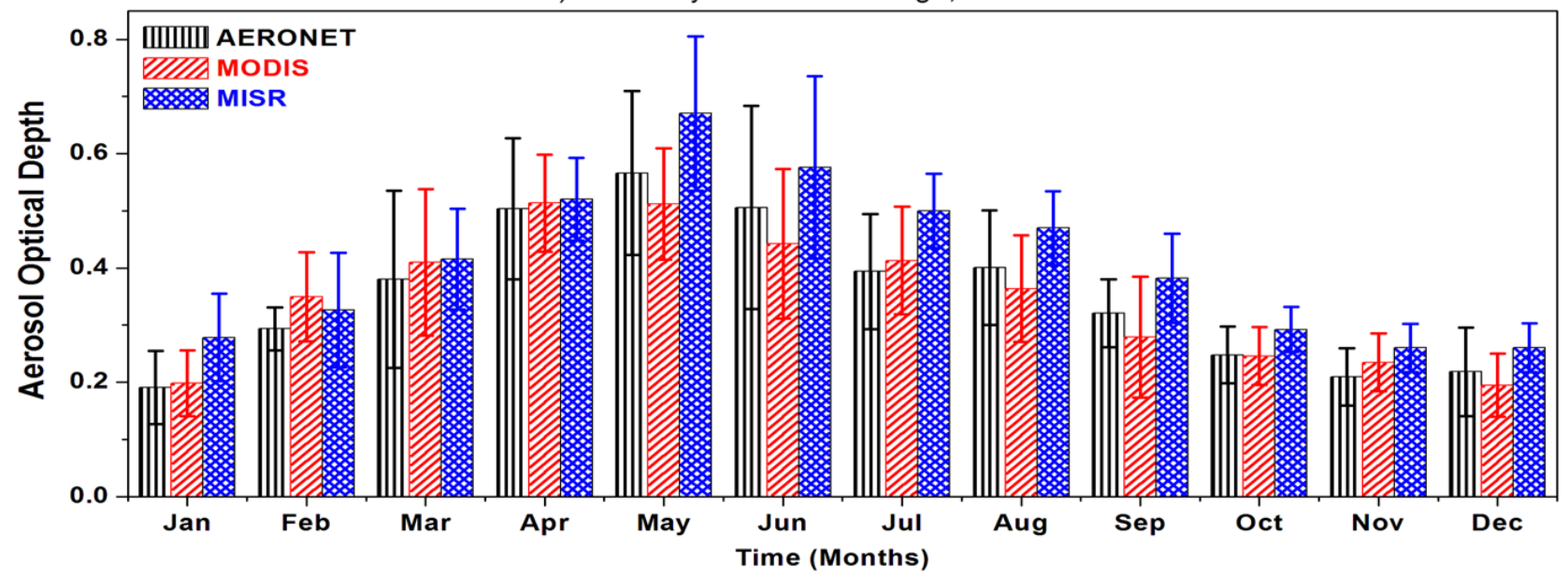

595 Figure 1: (a) Comparison of AOD from AERONER with both MISR and MODIS satellite retrieved products for the period 2003-2012. (b) Climatological cycle along with their standard deviations (shown as error bars) of AOD is calculated for the above period for ground based 598 stations and MODIS satellite products over the Solar Village (see Figure 2 for the location), 599 Saudi Arabia. 
(a) AOD(MISR) annual mean (2003-2016)

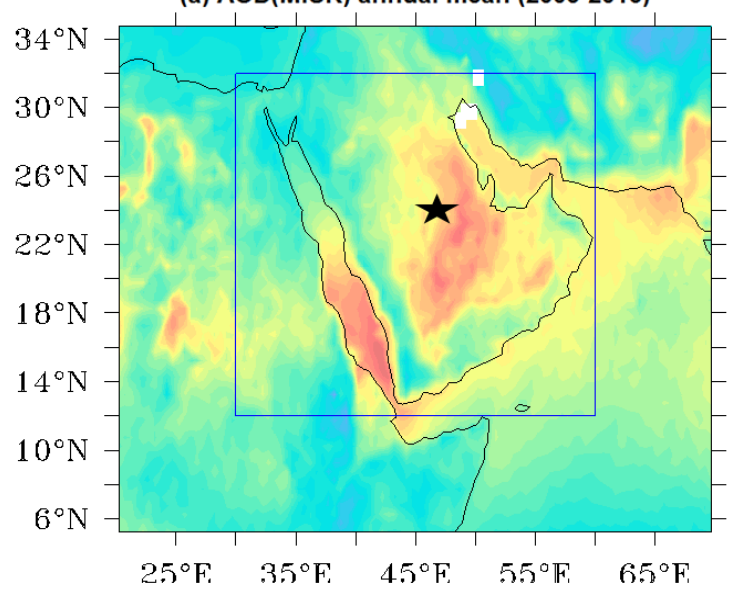

(b) AOD (MODIS) annual mean (2003 -2016)

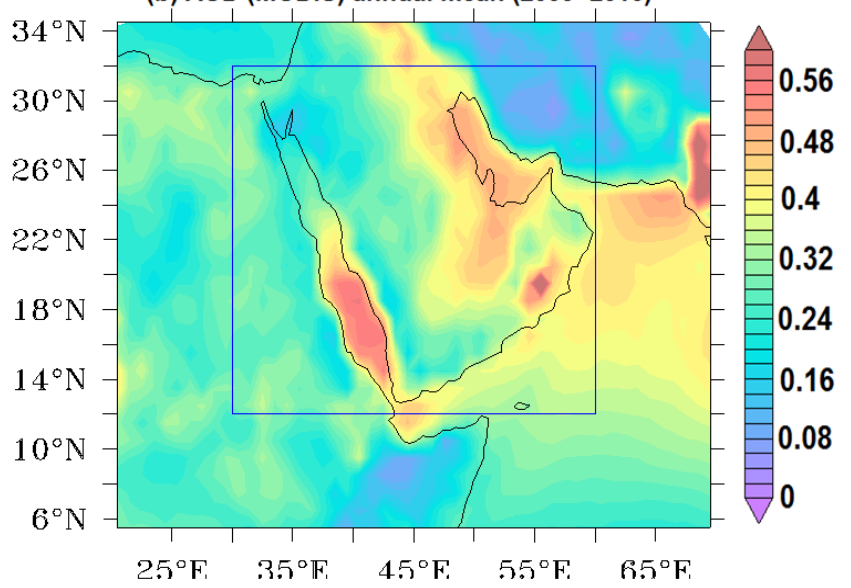

c)

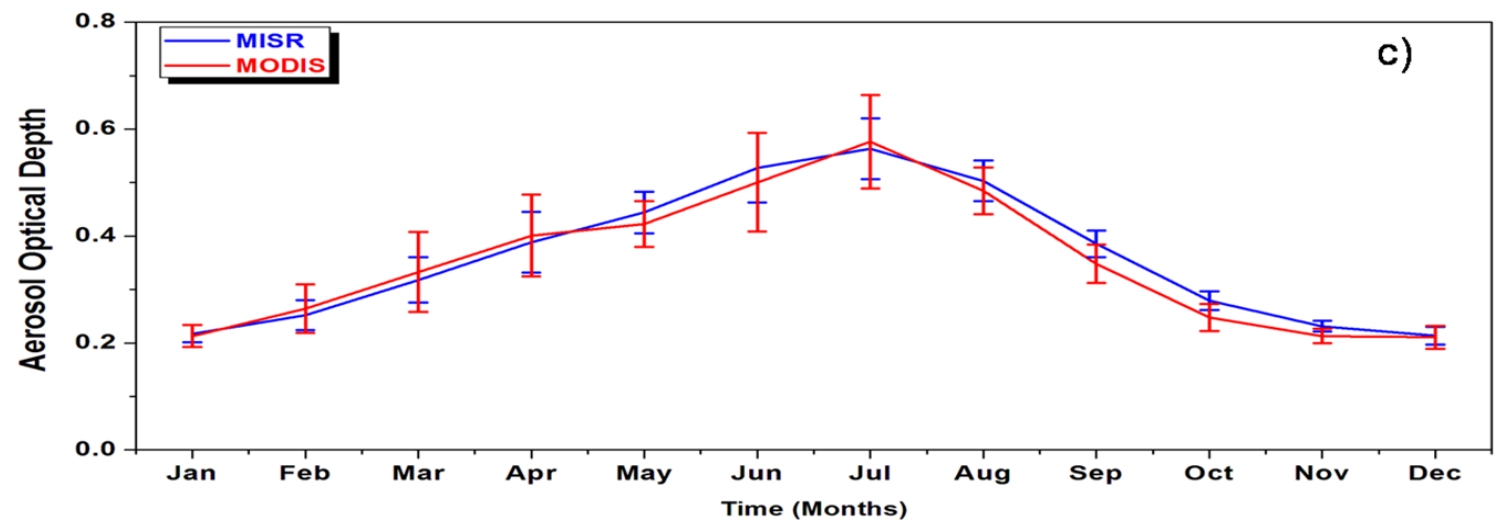

603 Figure 2: Annual mean of the Aerosol Optical Depth (AOD) over the Arabian Peninsula during 604 the period 2003-2016. (a) MISR, (b) MODIS and (c) annual cycle of the AOD for both satellite 605 products averaged over the indicate box $\left(12-30^{\circ} \mathrm{N}\right.$ to $\left.30-60^{\circ} \mathrm{E}\right)$. Blue color lines indicate the 606 MISR data and the red lines indicates the MODIS data. Location of the solar village is indicated 607 by the star in subplot (a). 
(a) AOD(MISR) - Wet period

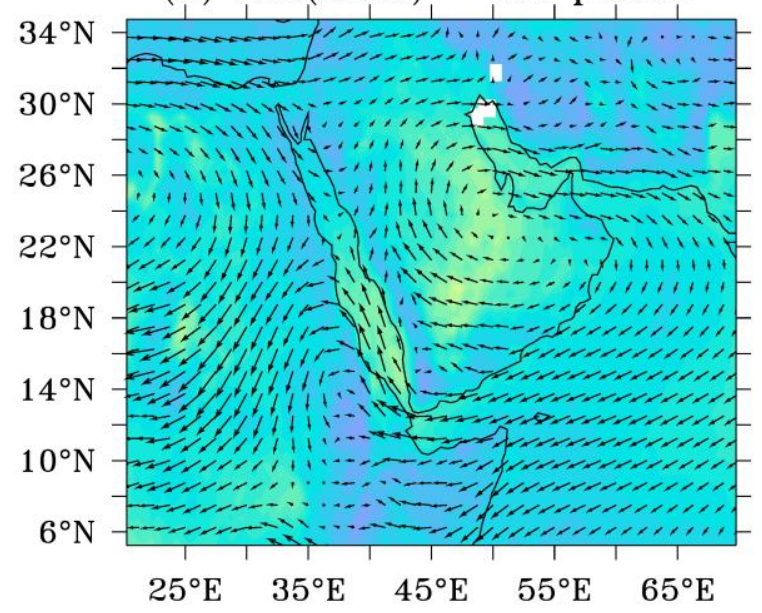

(c) AOD(MODIS) - Wet period

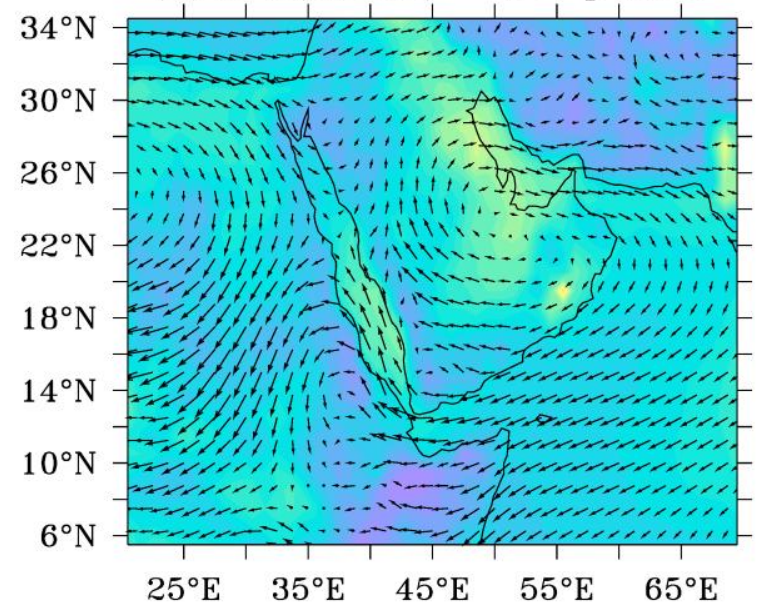

608

609

610

611 (b) AOD(MISR) - Dry period

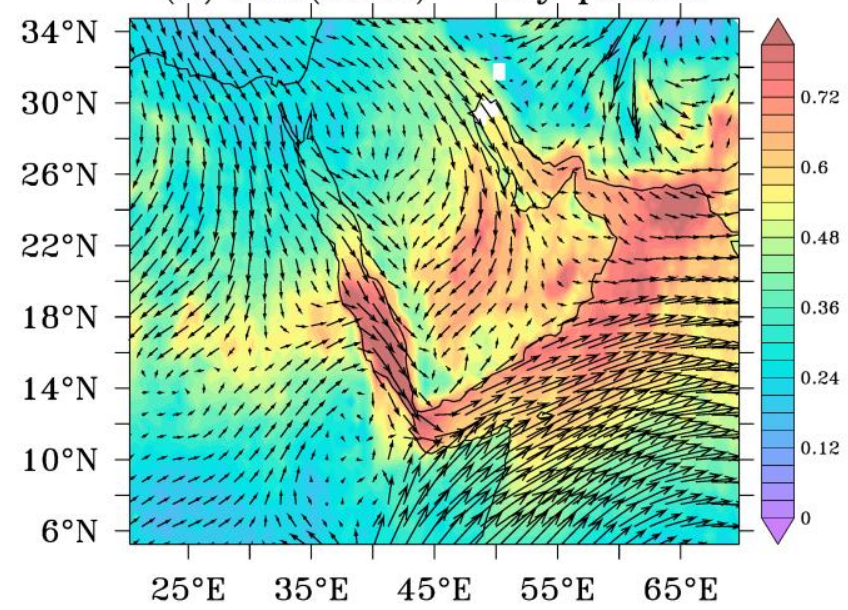

(d) AOD(MODIS) - Dry period

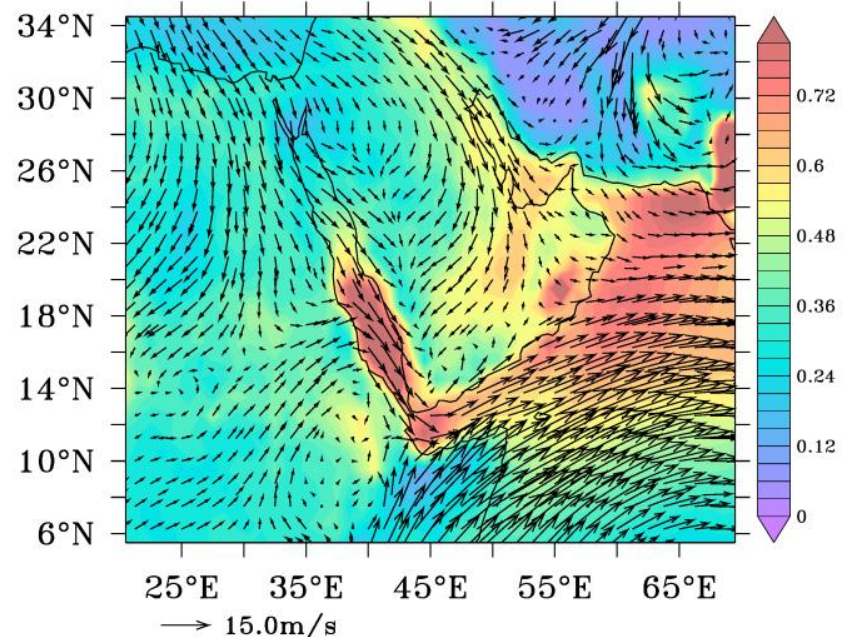

Figure 3: Seasonal distribution of the AOD over the AP during 2003-2016. (a) and (c) are wet seasons, and (b) and (d) are for dry seasons from both MISR and MODIS satellite products. 
(a) AOD(MISR)SD - Wet period

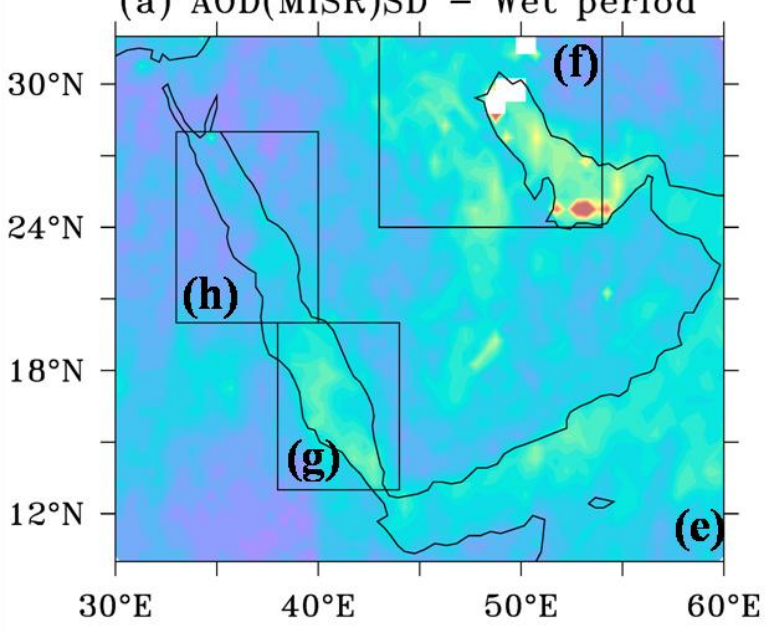

(c) AOD(MODIS)SD - Wet period

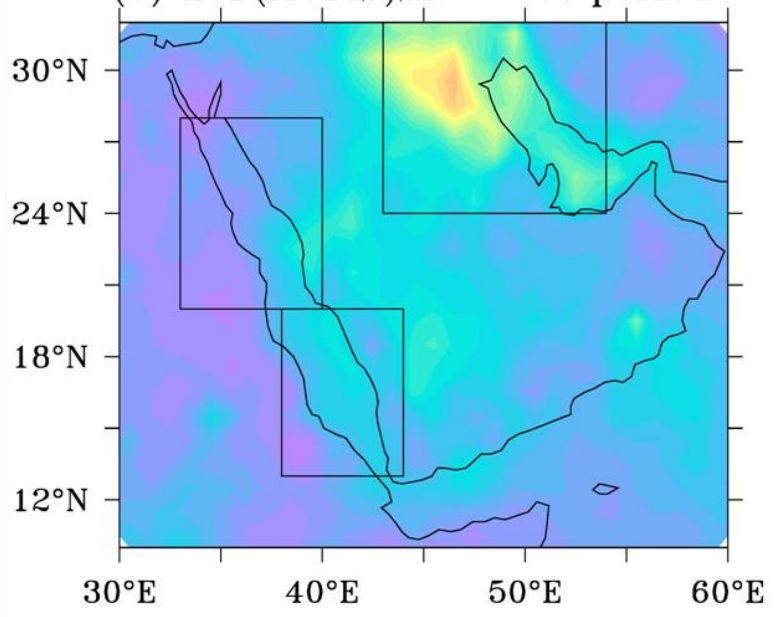

(b) AOD(MISR)SD - Dry period

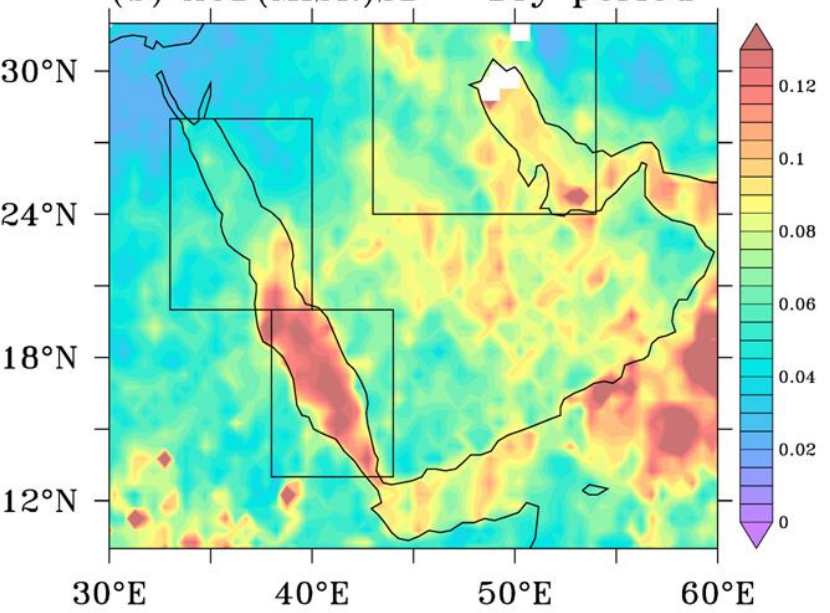

(d) AOD(MODIS)SD - Dry period

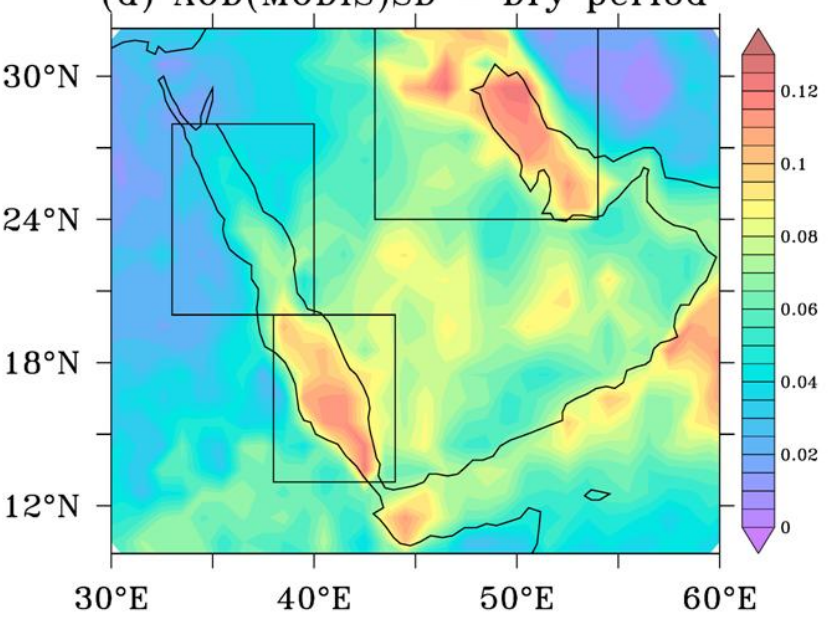

613 Figure 4: Spatial distributions of the standard deviations (SD) of the AOD over the Arabian

614 Peninsula during 2003-2016. (a) and (c) are for wet seasons, and (b) and (d) are for dry seasons 615 from both MISR and MODIS satellite products. Regions are indicated in the figure with (e) AP, 616 (f) NEAP,(g) SR and (h) NR. 

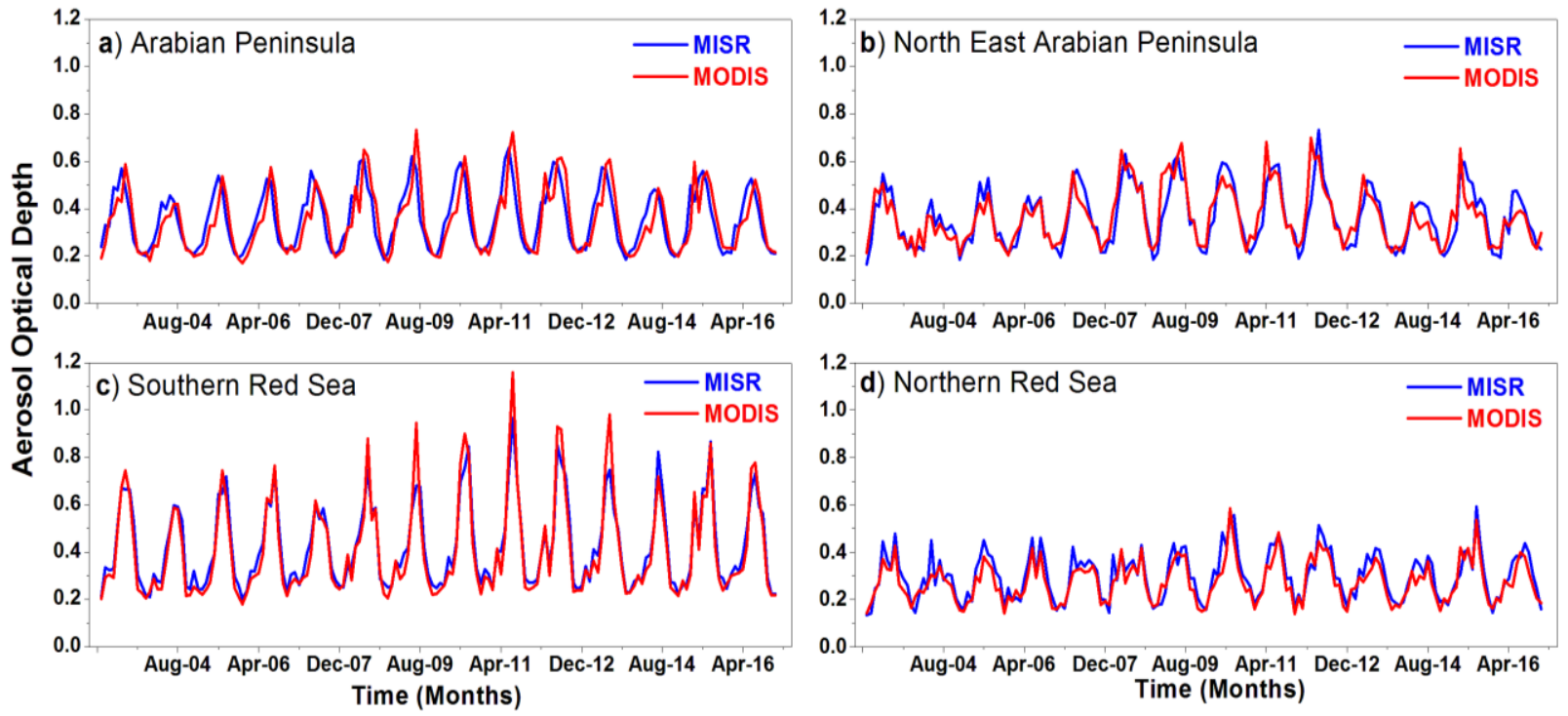

Figure 5: Time series of the AOD over the Arabian Peninsula (a), North East Arabian Peninsula (b), South Red Sea (c), and Northern Red Sea (d).

632 

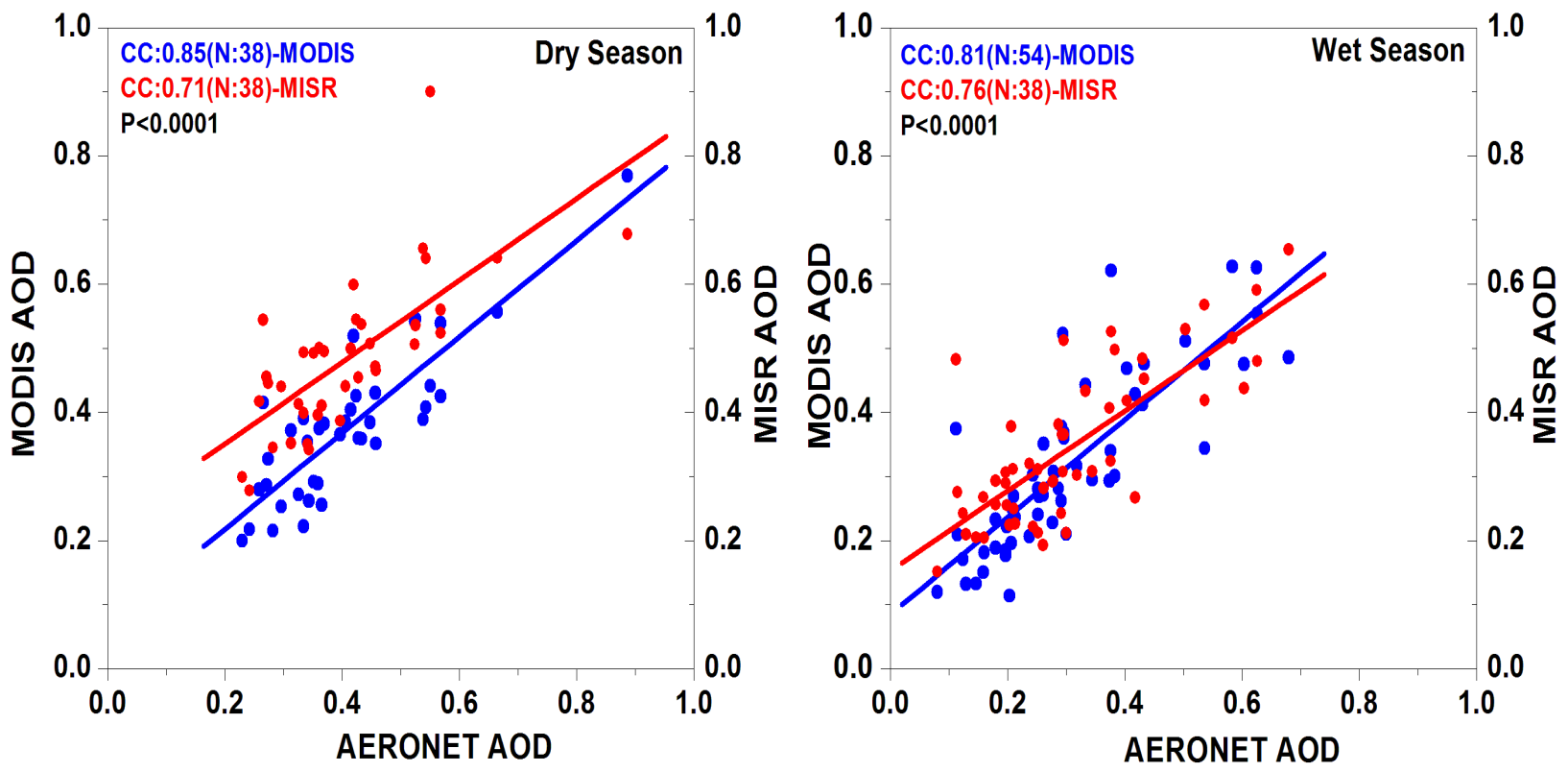

Figure 6: Scatter plots for the correlations coefficients (CC) with the AERONET AOD with respect to the MODIS and MISR satellite products. CCs were calculated from the monthly values of three datasets for dry (June to September) and wet (November -April) seasons. Blue color indicates CC between AERONET and MODIS and red color indicates AERONET and

653 MISR products. 


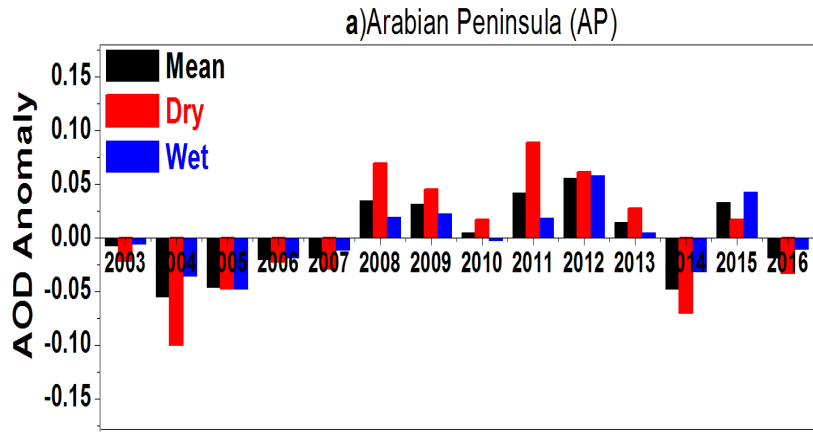

c) Southern Red Sea (SR)

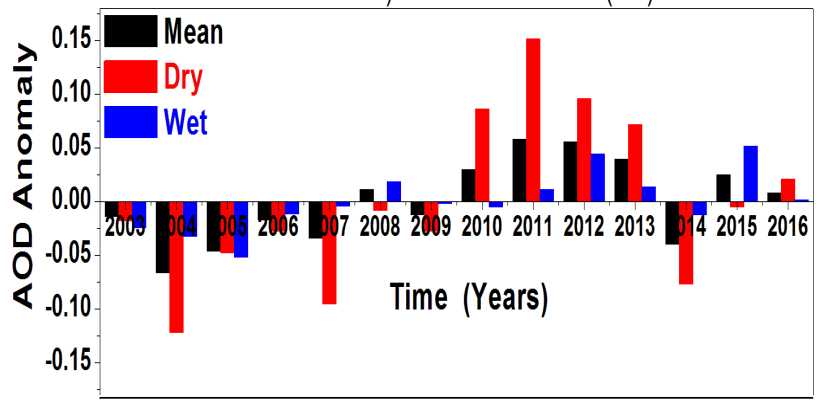

b) North East Arabian Peninsula (NEAP)

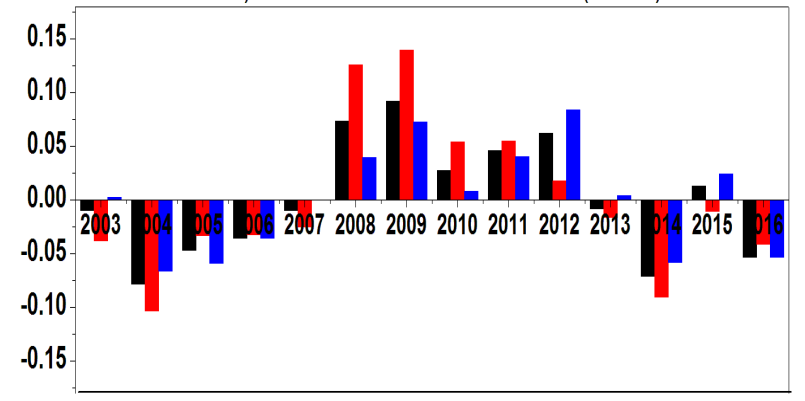

d) Northern Red Sea (NR)

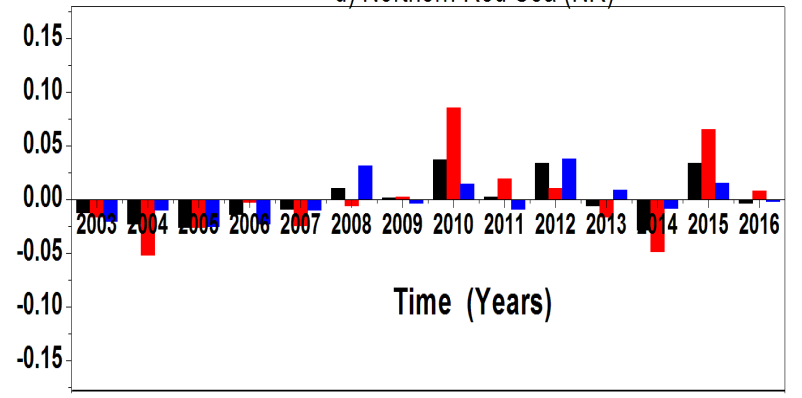

Figure 7: Interannual variations of the AOD anomalies over different regions of the Arabian

670

671

672

673 


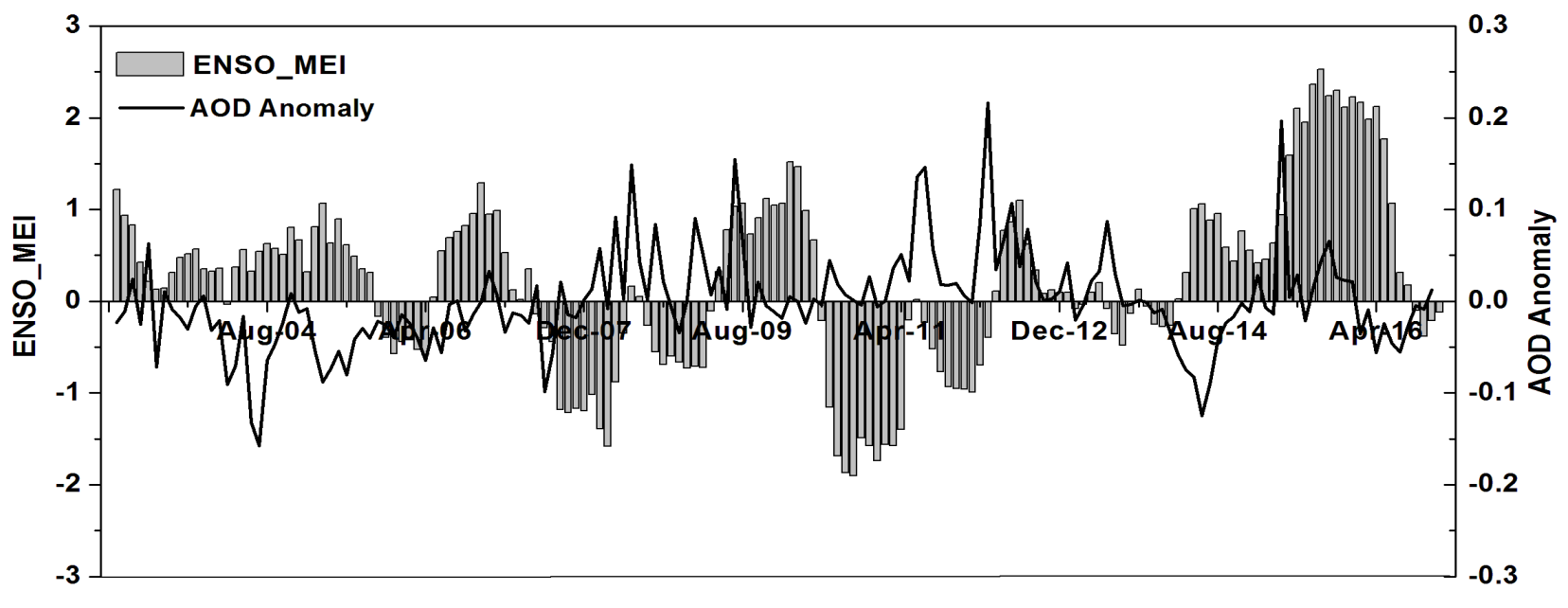

685 Figure 8: Time series of the Multivariate ENSO Index (MEI) with AOD (MODIS) anomaly 686 averaged over the Arabian Peninsula $\left(12-32^{\circ} \mathrm{N} ; 35: 60^{\circ} \mathrm{E}\right)$ for the period $2003-2016$. 
(a) AOD during EI Nino Period

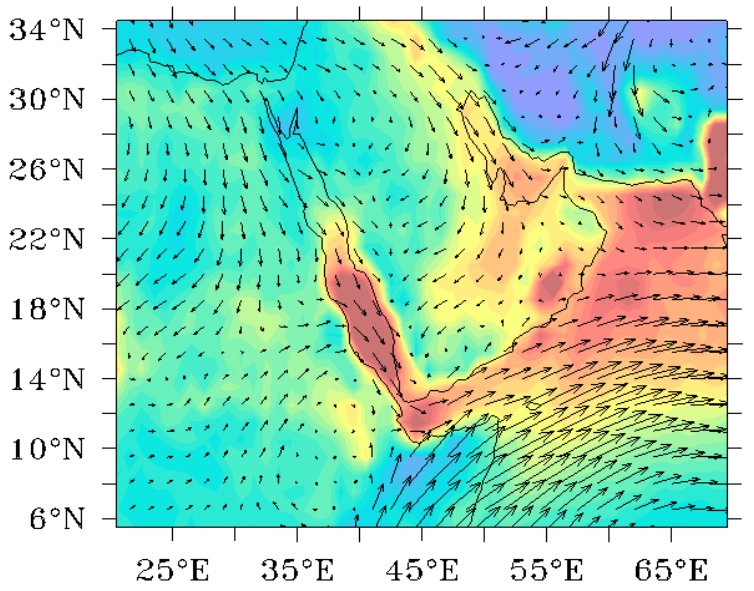

(b) AOD during La Nina Period

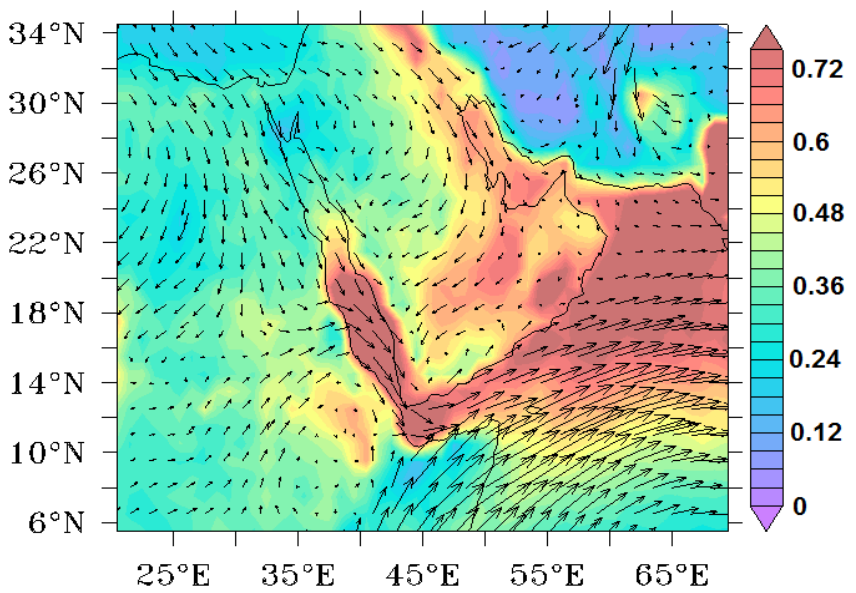

(c) AOD during La Nina -EI Nino

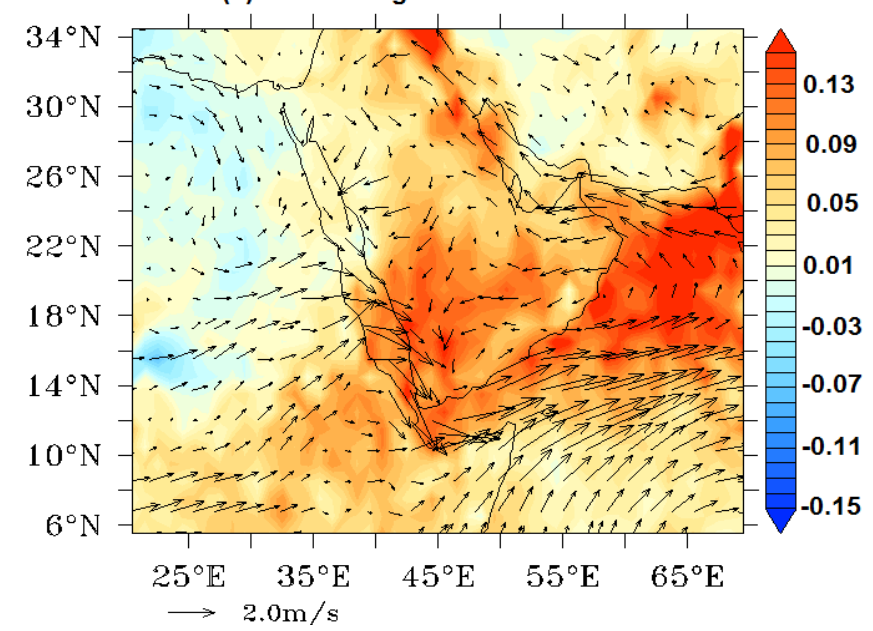

693 Figure 9. The composite mean of AOD and winds for (a) El Nino episodes, (b) La Nina episodes 694 during the 14 years duration of the study, and (c) difference between La Nina and El Nino 695 episodes. Winds are represented by arrows.

696

697

698

699

700

701 


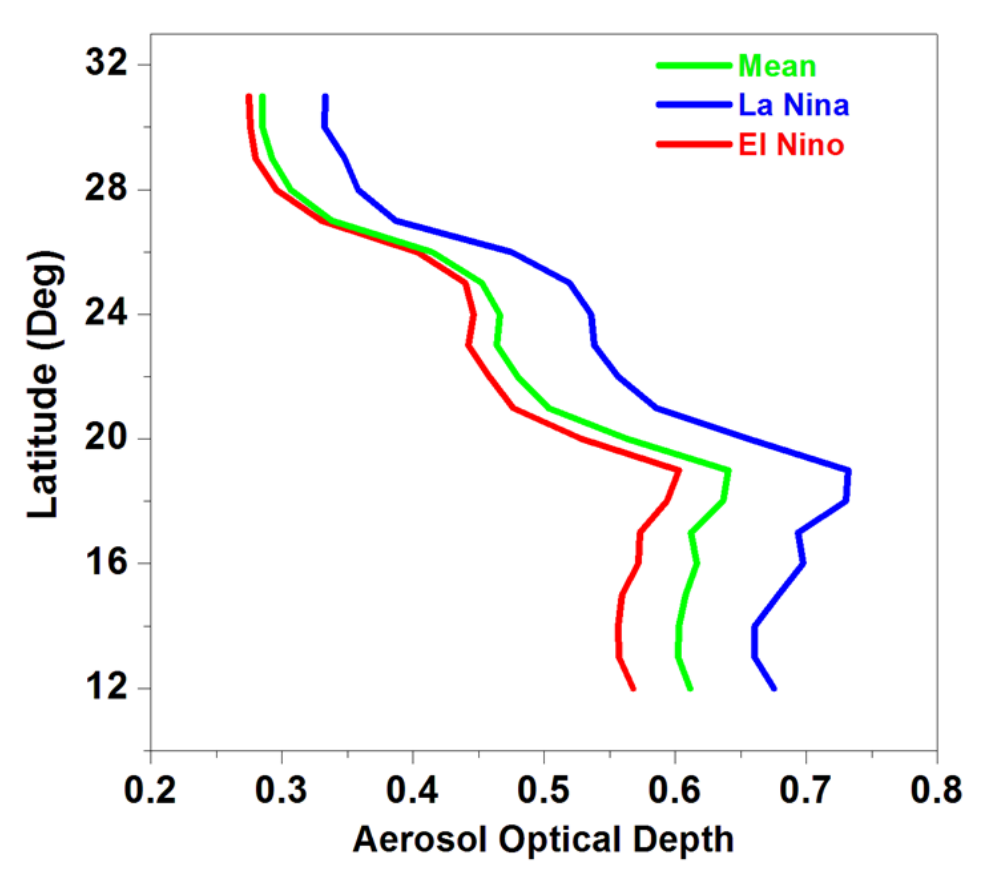

705 Figure 10 . Zonally averaged (longitudes between $35^{\circ} \mathrm{E}$ and $60^{\circ} \mathrm{E}$ ) AODs for the composite mean 706 of El Niño (red) and La Niña (blue) along with the mean (green). 
(a) VV during LaNina

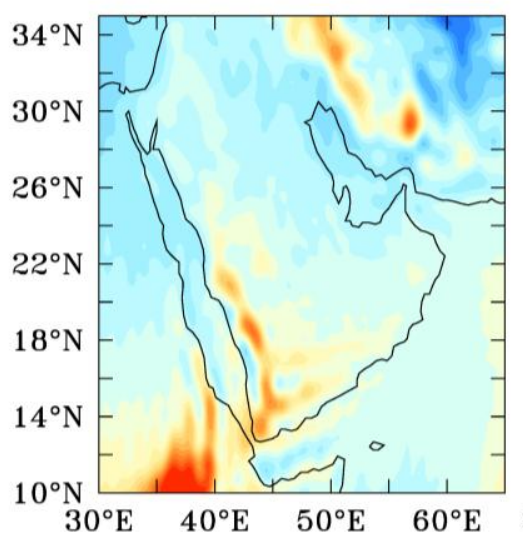

(d) MSL during LaNina

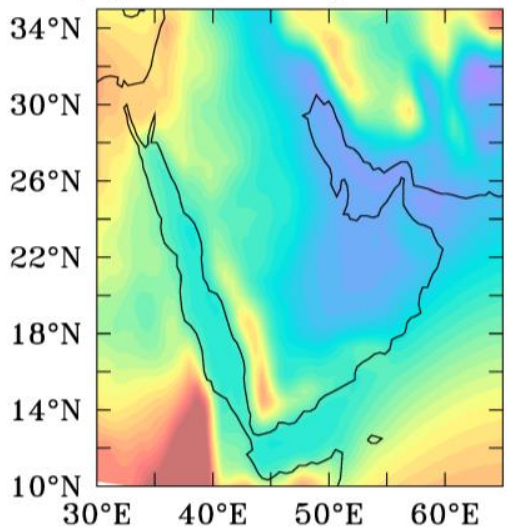

(b) VV during ElNino

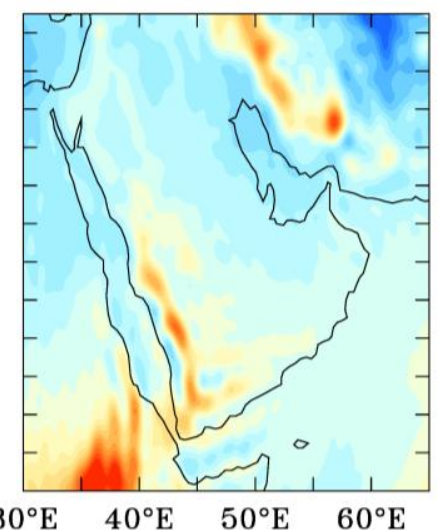

(e) MSL during ELNino

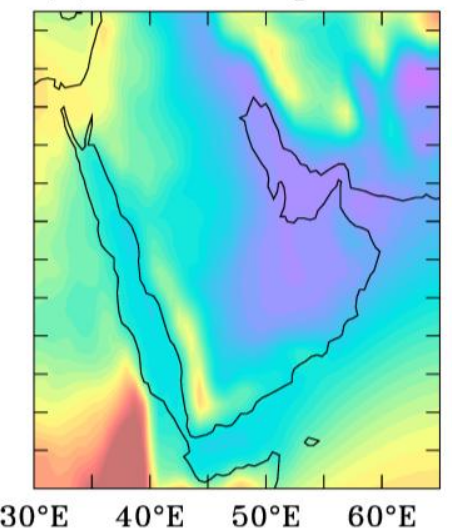

(c) VV LaNina - ElNino

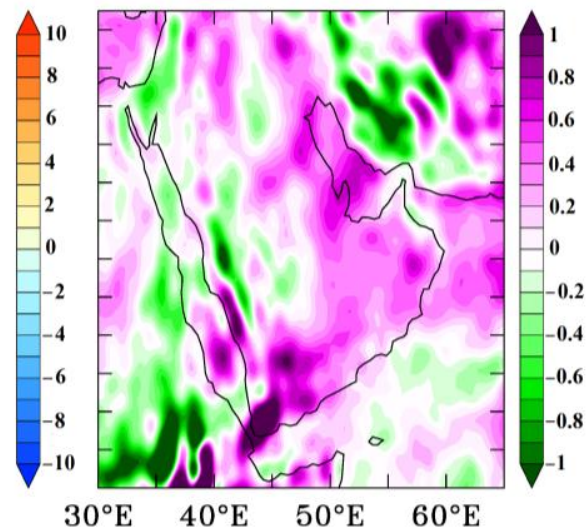

(f) MSL LaNina - ElNino

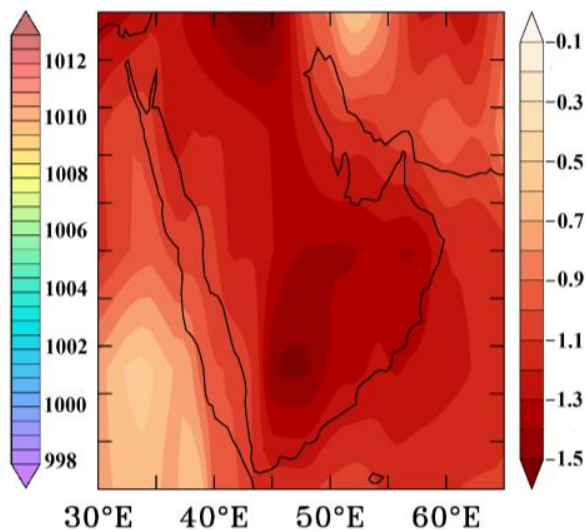

718 Figure 11: Composites of vertical velocities at $500 \mathrm{hPa}$ and sea level pressure during La Niña (a and d), during El Niño (b and e), difference between La Niña and El Niño (c and f). 
(a) Temp. during LaNina

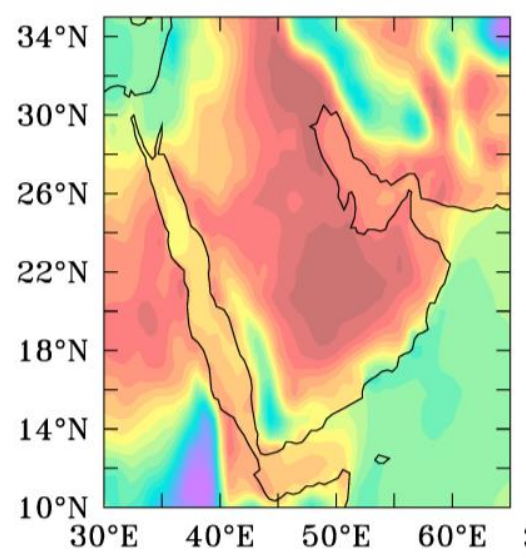

(d) TSR during LaNina

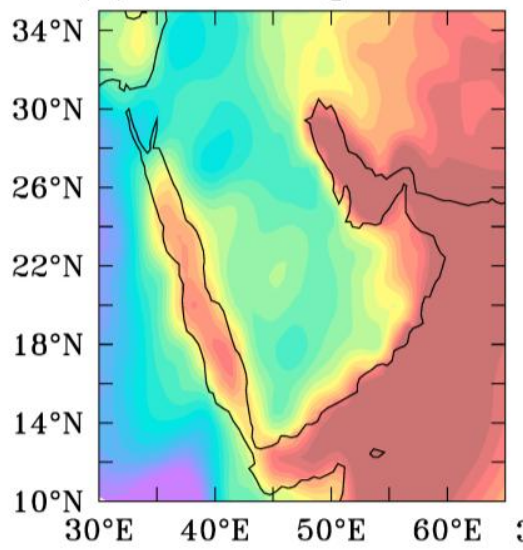

(b) Temp. during ElNino (c) Temp. LaNina - ElNino
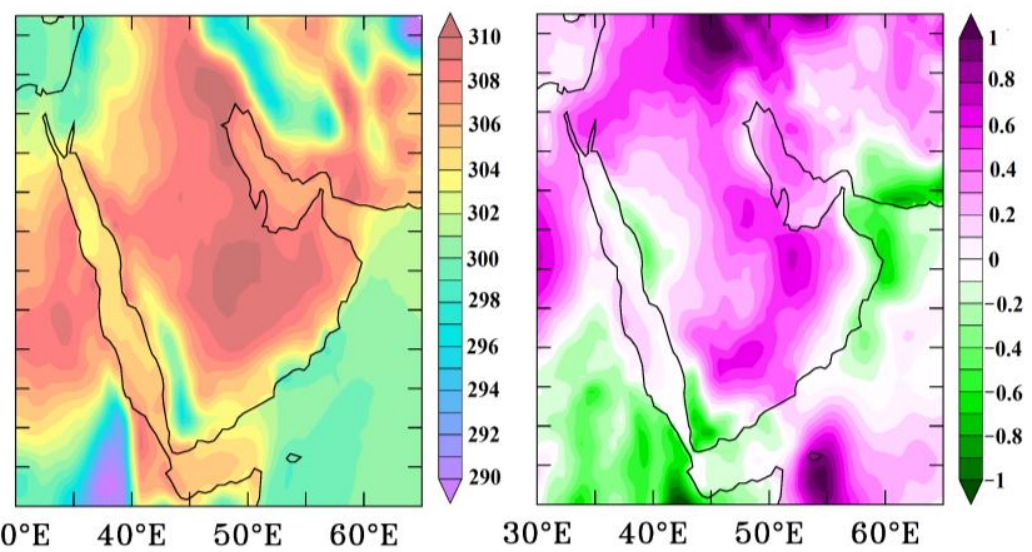

(e) TSR during ELNino

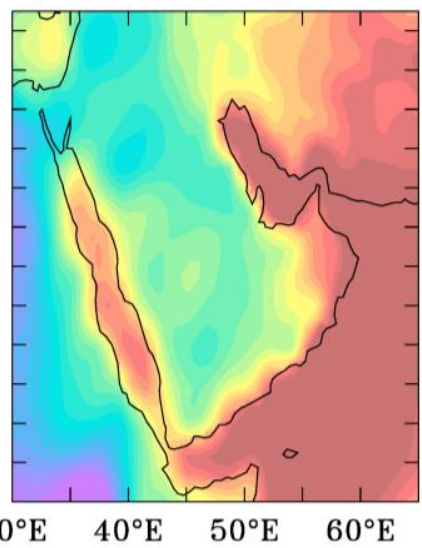

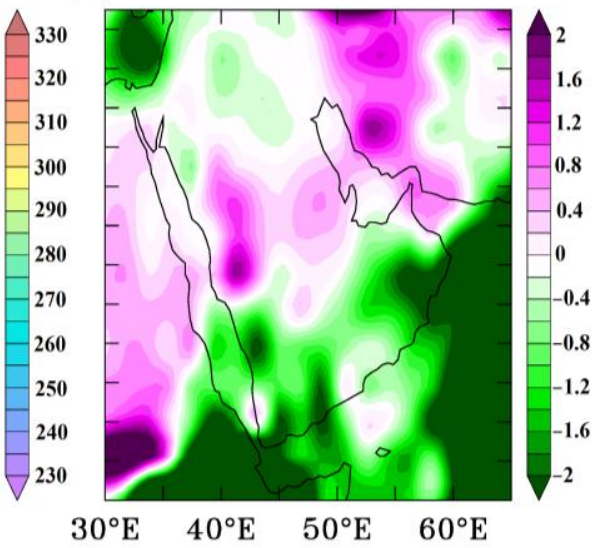

(f) TSR LaNina - ElNino

Figure 12: Composites of $2 \mathrm{~m}$ height temperature and total shortwave radiation during La Niña (a 729 and d), during El Niño (b and e), difference between La Niña and El Niño (c and f). 
